\title{
UMA BREVE HISTÓRIA (INDÍGENA) DA ERVA-MATE NA REGIÃO PLATINA: DA PROVÍNCIA DO GUAIRÁ AO ANTIGO SUL DE MATO GROSSO
}

\author{
JORGE EREMITES DE OLIVEIRA ${ }^{1}$
}

UFPel

PAULO MARCOS ESSELIN ${ }^{2}$

UFMS

\begin{abstract}
RESUMO: Neste artigo, os autores analisam a exploração da erva-mate (Ilex paraguariensis) na bacia platina. $O$ estudo se estende desde a Província do Guairá, no período colonial, até a incorporação do antigo sul de Mato Grosso, atual Estado de Mato Grosso do Sul, ao território brasileiro. Esta última situação ocorreu no século XIX, após o fim da guerra entre o Paraguai e a Tríplice Aliança (1864-1870) e com a implantação, na década de 1880, da Companhia Matte Larangeira na região. A empresa explorou durante décadas os ervais nativos, o território e o trabalho de comunidades guarani e kaiowá. Também explorou a mão de obra de trabalhadores não índios de origem paraguaia e brasileira, dentre outros. A economia ervateira é, pois, o fio condutor para uma análise mais ampla sobre um longo processo histórico e sociocultural.
\end{abstract}

PALAVRAS-CHAVE: história da erva-mate; história de Mato Grosso do Sul; história indígena.

RESUMEN: En este artículo los autores analizan la explotación de la yerba mate (Ilex paraguariensis) en la cuenca del río de la Plata. El estudio se extiende de la Provincia del Guairá, en el período colonial, hasta la fusión del antiguo sur de Mato Grosso, actual estado de Mato Grosso do Sul, al territorio brasileño. Esto último en el siglo XIX, después de la guerra entre Paraguay y la Triple Alianza (1864-1870) y la introducción, en la década de 1880, de la Compañia Matte Larangeira en la región. La compañía explotó durante décadas los yerbales nativos, el territorio y el trabajo de las comunidades Guaraní y Kaiowá. También se explotó la mano de obra de los trabajadores no indígenas de origen paraguayo y brasileño, entre otros. La economía yerbatera es, pues, el hilo conductor de un análisis más amplio acerca de un largo proceso histórico y sociocultural.

PALABRAS CLAVE: historia de la yerba mate; historia de Mato Grosso do Sul; historia indígena.

\footnotetext{
${ }^{1}$ Doutor em História (Arqueologia) pela Pontifícia Universidade Católica do Rio Grande do Sul com estágio de pós-doutorado em Antropologia Social pelo Museu Nacional da Universidade Federal do Rio de Janeiro. Docente da Universidade Federal de Pelotas e bolsista de produtividade em pesquisa do CNPq. Email: eremites.br@gmail.com.

${ }^{2}$ Doutor em História (História Ibero-Americana) pela Pontifícia Universidade Católica do Rio Grande do Sul com estágio de pós-doutorado em História pela Universidade de São Paulo. Docente da Universidade Federal de Mato Grosso do Sul. E-mail: paulo.esselin@gmail.com.
} 


\begin{abstract}
In this article the authors analyze the exploitation of yerba mate (Ilex paraguariensis) in Plata River Basin. The study focuses on an area that covers the Guairá Province, from the colonial period, until the incorporation of the South Region of the former State of Mato Grosso, currently the State of Mato Grosso do Sul, in Brazil. This situation occurred after the end of the war between Paraguay and the Triple Alliance (1864-1870) and the introduction, in 1880s, of the Company Matte Larangeira in region. The firm explored the native herbals for decades, in the territory as well as the work of Guarani and Kaiowá communities. The enterprise also explored the manual labor of non-Indigenous workers of Paraguayan and Brazilian origin, among others. The economic activity of the yerba mate is thus the common thread for a broader analysis of a long historical and socio-cultural process.
\end{abstract}

KEYWORDS: history of yerba mate; history of Mato Grosso do Sul State; indigenous history.

\title{
Considerações iniciais
}

No presente trabalho consta uma breve análise sobre o processo histórico e sociocultural relacionado à exploração, para fins comerciais, da erva-mate (/lex paraguariensis) na região platina. $O$ assunto é abordado de maneira ampla e com base em fontes escritas e referências bibliográficas sobre o tema, muitas das quais foram (re) visitadas para a elaboração do estudo. Para este propósito, foi definido um recorte temporal que abrange desde a chegada dos espanhóis à Província do Guairá, no período colonial, até, sobretudo, a definitiva incorporação do antigo sul de Mato Grosso, atual Estado de Mato Grosso do Sul, ao território nacional do Brasil ${ }^{3}$. Esta última situação ocorreu após a guerra entre o Paraguai e a Tríplice Aliança (1864-1870), mais conhecida na historiografia como Guerra do Paraguai ou Guerra da Tríplice Aliança, quando os limites entre os dois países foram redefinidos e houve a instalação de um grande empreendimento ervateiro na região, a Companhia Matte Larangeira.

O nome da referida empresa faz alusão ao sobrenome de um de seus fundadores, o brasileiro Thomaz Larangeira, quem teria sido

\footnotetext{
${ }^{3}$ Ao longo deste trabalho a expressão "antigo sul de Mato Grosso" é usada para se referir à área que, grosso modo, corresponde ao atual Estado de Mato Grosso do Sul, criado em 1977 e implantado em 1979, durante o regime militar (1964-1985). No âmbito da historiografia sul-mato-grossense, geralmente o termo é mais recorrido para designar o extremo sul da antiga unidade da federação, o Mato Grosso uno, onde foi desenvolvida a economia ervateira a partir do século XIX.
} 
voluntário para lutar na guerra e contou com o apoio do português Francisco Mendes Gonçalves, natural da freguesia de Campanário, no arquipélago da Madeira, para a idealização e execução do empreendimento. Por isso, a partir de 1918, a sede da firma no Brasil recebeu o nome da terra natal de seu sócio, Fazenda Campanário. Em 1874 este seu parceiro fundou, em Buenos Aires, cidade onde havia se radicado no pós-guerra, a Francisco Mendes \& Companhia, responsável pela distribuição da erva-mate mato-grossense e outros produtos. À vista disso, nota-se que, durante sua existência, a Companhia Matte Larangeira fez parte de um poderoso conglomerado ervateiro, articulado em uma rede multinacional.

Thomaz Larangeira obteve autorização do governo central para explorar com exclusividade uma vasta extensão de terras devolutas, onde havia ervais nativos em territórios ocupados por comunidades guarani e kaiowá. A concessão inicial foi dada com o Decreto Imperial $n^{\circ} 8.799$, de 9 de dezembro de 1882, quando o empreendimento foi chamado de Empresa Matte Larangeira. Em 1890, no começo do período republicano, a autorização foi renovada pelo governo federal através do Decreto $\mathrm{n}^{\circ}$ 520. Com isso a empresa ampliou sua área de exploração para aproximadamente 5 milhões de hectares. Em 1891 passou a atuar com o nome de Companhia Matte Larangeira e manteve a referida autorização por meio do Decreto $n^{\circ} 436 C$ e outros posteriores ajustes contratuais. Foi com esta designação que ficou mais conhecida na historiografia e permaneceu até 1902. A partir de então, foi denominada Larangeira, Mendes \& Companhia e formalmente seguiu à frente da economia ervateira na região até 1949 , quando o contrato de arrendamento foi rescindido pelo governo central e logo em seguida a firma encerrou suas atividades (CORRÊA FILHO, 1925, 1957, 1969; ARRUDA, 1997; BRAND, 1997; VILELA DA SILVA, 1997; GUILLEN, 1999; JESUS, 2004; BRAND et al., 2005; FERREIRA, 2007; QUEIROZ, 1997, 2010b).

A história da economia da erva-mate, portanto, constitui-se em um elemento de grande importância para compreender a consolidação do processo de colonização europeia e euroamericana na região platina colonial. Torna-se, ainda, relevante para entender o processo ligado à posse e incorporação do antigo sul de Mato Grosso ao território nacional do Brasil. Isso tudo aconteceu a partir da exploração da mão de obra de 
coletivos indígenas, do conhecimento que possuíam e possuem sobre a planta e dos ervais nativos existentes em seus territórios. Este é, portanto, um elemento relevante para compreender o sucesso do empreendimento ervateiro na região, bem como os motivos que levaram comunidades guarani e kaiowá a perderem seus territórios ao longo do século XX. Algumas dessas áreas passaram a ser reivindicadas como terras indígenas a partir dos anos 1980, sobremaneira após a promulgação da Constituição Federal de 1988. Desta situação resultam vários litígios judiciais e longas disputas vis-à-vis pela posse de terras indígenas envolvendo, em sua grande maioria, comunidades originárias e ruralistas.

Em suma, neste artigo consta uma singela contribuição à história da região platina, cujo fio condutor para analisar processos mais amplos é a economia ervateira iniciada no período colonial. Trata-se, em linhas gerais, de um texto datado e produzido com a preocupação de dar maior visibilidade à trajetória de povos indígenas de língua guarani, os quais por vezes são tratados como figurantes atemporais, exóticos e desprezíveis no âmbito da historiografia nacional e regional.

\section{Do Rio da Prata à Província do Guairá}

Os espanhóis que aportaram às margens do Rio da Prata em janeiro de 1536, após longa viagem da Península Ibérica até a porção meridional da América do Sul, tinham o propósito de iniciar o processo de colonização europeia da região. Também queriam chegar à lendária Sierra de la Plata de que muitos europeus ouviram falar desde meados do século XVI. Tratava-se de um lugar onde haveria grande quantidade de metais preciosos, especialmente a prata, localizada, ao que tudo indica, na atual região andina de Cerro Rico de Potosí, Bolívia. A popularidade da lenda fez com que Sebastião Caboto e outros europeus passassem a denominar, a partir de 1525, aquele rio com o próprio nome da área montanhosa. Por isso no começo de fevereiro de 1536 os espanhóis ali fundaram um porto defendido por dois pequenos fortes. A localidade foi denominada por Pedro de Mendoza, o primeiro adelantado do Rio da Prata, de Puerto de Nuestra Señora Santa María del Buen Aire. O nome serviu para designar o lugar que posteriormente deu origem à cidade de Buenos Aires, atual 
capital da Argentina (CHAVES, 1968; GUSMÁN, 1980; PAYRÓ, 2007). A região há muito estava povoada por diferentes povos indígenas, como os antigos Querandíes e Tehuelche, assim chamados genericamente no período colonial. A fundação do porto constitui-se assim em um evento para compreender o processo de invasão e colonização europeia da região platina e seus desdobramentos ${ }^{4}$.

Assim como ocorreu em outras partes do continente, desde os primeiros momentos os povos indígenas estabelecidos na área passaram a oferecer várias formas de resistência aos espanhóis que tentavam se instalar e se apoderar de seus territórios. Em pouco tempo o destino do porto foi selado e os nativos passaram a desferir constantes ataques, isolando os invasores até a destruição da localidade em 1541. Diante da situação, e também impulsionados pela busca de metais preciosos, os europeus abandonaram o lugar e seguiram em expedição à procura de um novo local onde pudessem se estabelecer. Navegaram pelo Rio Paraná acima e mais ao norte chegaram até o curso do Rio Paraguai, onde em 1537 outros espanhóis haviam fundado o forte de Nuestra Señora Santa María de la Asunción. A localidade foi elevada à categoria de cidade em 1541 por Domingo Martínez de Irala e hoje em dia corresponde à atual capital do Paraguai.

[...] los españoles solamente consideraron a Asunción como etapa indispensable en su camino hacia la Sierra de la Plata, el sentido más hondo de la fundación de esa ciudad se encuentra em otro plano. A medida que se desvanecía la ilusión de conquistar nuevas tierras del oro, los españoles se consagraban con éxito creciente a la agricultura. Favorecido por las condiciones geográficas y teniendo a su disposición abundante mano de obra indígena, pronto se inició un notable auge económico (RAMOS, 1974, p. 18).

De pronto os espanhóis buscaram estabelecer com os indígenas dali relações de trabalho e dominação análogas às que seus predecessores mantinham em outras partes das Américas, conhecidas

\footnotetext{
${ }^{4}$ A palavra "invasão" é aqui utilizada em contraposição aos termos "descobrimento" e "conquista", pois os povos indígenas contemporâneos não se sentem descobertos, conquistados ou subjugados, pelo contrário. Geralmente se percebem ,no Brasil e em outros países americanos, como povos resistentes, cada qual com etnônimos, histórias e culturas particulares.
} 
como encomiendas. Trata-se de uma instituição que permitia aos colonos explorar a força de trabalho de comunidades nativas. Em contrapartida, os encomenderos eram obrigados a introduzir os índios à civilização europeia, isto é, ensinar-lhes a língua castelhana, religião católica, estrutura política espanhola etc., além de manter em cada aldeia uma igreja e a figura do cura (GADELHA, 1980). Com efeito, a encomienda foi uma das primeiras estratégias coloniais para incorporar os indígenas, por meio da aculturação e tentativas de dominação, à civilização tal qual era concebida na Península Ibérica. Isso foi feito através da negação de que os povos indígenas tivessem humanidade e, por conseguinte, cultura, organização social, religião, economia e historicidade próprias (MELIÀ, 1990).

Inicialmente a exploração da mão de obra nativa, inclusive com o objetivo de sustentar a agricultura local, levou os colonos espanhóis a praticarem várias formas de violência contra os índios que habitavam as cercanias de Assunção. Diante da pressão do trabalho compulsório e do pagamento de tributos, bem como por conta das doenças causadas por agentes patogênicos trazidos de além-mar, muitas comunidades nativas pereceram: depopulação, desterritorialização, desestruturação da organização social original etc. No âmbito deste contexto seiscentista, aqui apresentado de maneira muito pontual, os espanhóis sediados na cidade começaram o processo de expansão ibérica na região platina.

Em fins de 1553 os invasores buscaram estabelecer novas vias de comunicação e comércio na região. Avançaram a colonização até as margens dos rios Paraná e do Prata, procurando assegurar a posse das áreas e obter o controle da mão de obra indígena ali existente. Fundaram um povoado chamado Villa de Ontiveros à margem esquerda do Paraná, cerca de uma légua e meia acima do Salto de Sete Quedas, também conhecido como Saltos del Guairá. O local estava situado no território de um povo indígena de língua guarani, historicamente chamado de Canindeyú, mas a cidade não prosperou. Diante da situação, em 1557 Ruy Díaz de Melgarejo comandou o translado dos remanescentes da população local para outro lugar, situado cerca de três léguas ao norte dali, na confluência do Paraná com o Rio Piquiri. Denominou o novo povoado de Ciudad Real del Guayrá, nome homônimo a de um cacique daquela região habitada por várias comunidades indígenas de língua 
guarani. Por volta de 1570 os espanhóis ainda fundaram Villa Rica del Spirictu Santu, situada na foz do Rio Corumbataí com o Ivaí, nas terras da comunidade liderada pelo cacique Coraciberá. Todas essas fundações, cujas populações eram majoritariamente constituídas por índios, estavam localizadas em territórios ocupados desde tempos pré-coloniais por comunidades chamadas genericamente de guarani na literatura de natureza arqueológica, etno-histórica e etnológica (SUSNIK, 1965; CARDOZO, 1968; CHAVES, 1968; GUSMÁN, 1980; BASTOS, 1979; PARELLADA, 2014).

A região foi denominada Província del Guayrá e sua área abrangia desde aquelas localidades e adjacências até a porção meridional do atual estado brasileiro de Mato Grosso do Sul, na bacia platina. Era formada por florestas densas, nas quais há muito existia uma planta bastante conhecida e chamada em guarani de ka'a, a erva-mate (//ex paraguariensis). Suas folhas eram especialmente utilizadas pelos indígenas ali estabelecidos para a produção de uma espécie de chá estimulante, denominado atualmente de ka'ay, originalmente mais consumido em contextos cerimoniais e religiosos. A erva-mate também era utilizada por outros povos indígenas para produzir bebidas semelhantes, inclusive entre comunidades originárias do Chaco e dos Andes, de onde a espécie não é nativa ou endêmica. A própria palavra mate, por exemplo, deriva do quéchua mati, vocábulo usado para designar o recipiente - geralmente uma cabaça ou porongo - onde era preparada e servida a bebida.

A situação apontada sugere que desde muito tempo a planta circulava em uma grande rede interétnica de relações sociais, a qual abrangia uma vasta extensão territorial na América do Sul. Ademais, a ocorrência de ervais nativos, isto é, próprios ou originários da região, não é um fenômeno meramente natural, pelo contrário. Áreas assim ocorrem em paisagens humanizadas, especialmente em territórios ocupados desde uns 2000 anos atrás por povos indígenas falantes da língua guarani, portadores da tradição tecnológica ceramista tupi-guarani, assim conhecidas por arqueólogos, etno-historiadores e etnólogos (NOELLI, 1998, 2000 e 2004; EREMITES DE OLIVEIRA e VIANA, 2000; LANDA, 2005; EREMITES DE OLIVEIRA, 2007; EREMITES DE OLIVEIRA e 
PEREIRA, 2009)5. Em praticamente todos os biomas situados na parte leste da América do Sul, como ocorre no Cerrado, no Pantanal e na Amazônia, paisagens humanizadas, a exemplo de palmeirais de origem antrópica, foram estudadas e são conhecidas na literatura especializada (POSEY, 1987; MEGGERS, 2001; POLITIS, 2007; EREMITES DE OLIVEIRA, 2012a). Este é caso de formas de manejo agroflorestal, incluindo o transplante de mudas de plantas de um lugar para outro e/ou os cuidados para deixá-las crescer frente a outras espécies competitivas. Significa dizer que os antigos ervais nativos da região platina são paisagens humanizadas, ou seja, registros materiais de relações sociais no tempo e espaço, apresentados sob forma de ecofatos, assim percebidas por arqueólogos. Fazem parte da "certeza sensível" de que Marx e Engels tratam em $A$ Ideologia Alemã ao criticarem as ideias de Feuerbach:

Sabe-se que a cerejeira, como quase todas as árvores frutíferas, foi transplantada [importada] para nossas zonas pelo comércio, há alguns séculos apenas, e foi, portanto, tão somente através dessa ação de uma determinada sociedade em uma época determinada que foi dada à "certeza sensível" de Feuerbach (MARX e ENGELS, 1986, p. 67).

Em estudos mais recentes, com destaque para aqueles realizados por etnólogos e arqueólogos, áreas assim são chamadas de florestas antrópicas (BALÉE, 2010; BALÉE et al., 2014; FEIJÓ, 2015; e outros). Originalmente estão associadas a sistemas tradicionais de conhecimentos, desenvolvidos por comunidades indígenas para a humanização das paisagens, segundo seus usos, costumes e tradições. Nesta linha de raciocínio, a própria erva-mate pode ser considerada como uma planta semidomesticada, a saber:

Emprego o termo "semidomesticada" para indicar plantas que são intencionalmente manipuladas pelos índios, os quais conscientemente modificam o habitat do

\footnotetext{
5 As comunidades portadoras da tradição tupi-guarani, grosso modo, correspondem aos atuais Guarani (também chamados de Nandeva), Kaiowá e Mbyá, povos originários falantes da língua guarani que se identificam dessa forma no Brasil. São mais conhecidos no Paraguai como Avá Guaraní (também citados como Avá Chiripá), Paĩ Tavyterã (ou simplesmente Paĩ) e Mbyá, respectivamente. Nota-se, com efeito, que apenas os Guarani se autoidentificam com o mesmo nome da língua que falam, diferentemente, por exemplo, dos Kaiowá estabelecidos em Mato Grosso do Sul.
} 
vegetal para estimular-lhe 0 crescimento. As conseqüências genéticas deste processo são ainda desconhecidas, mas merecem ser estudadas em profundidade (POSEY, 1987, p. 175).

De outra forma, caso não tivesse sido manipulada pelos índios desde tempos pré-coloniais, teria sido muito difícil ou inviável ampliar o tamanho dos ervais nativos para sua exploração econômica, como ocorreu a partir do século XVI.

Figura 1: Representação cartográfica da região do Guairá, onde iniciou a colonização espanhola e a exploração dos ervais nativos da bacia do Prata.

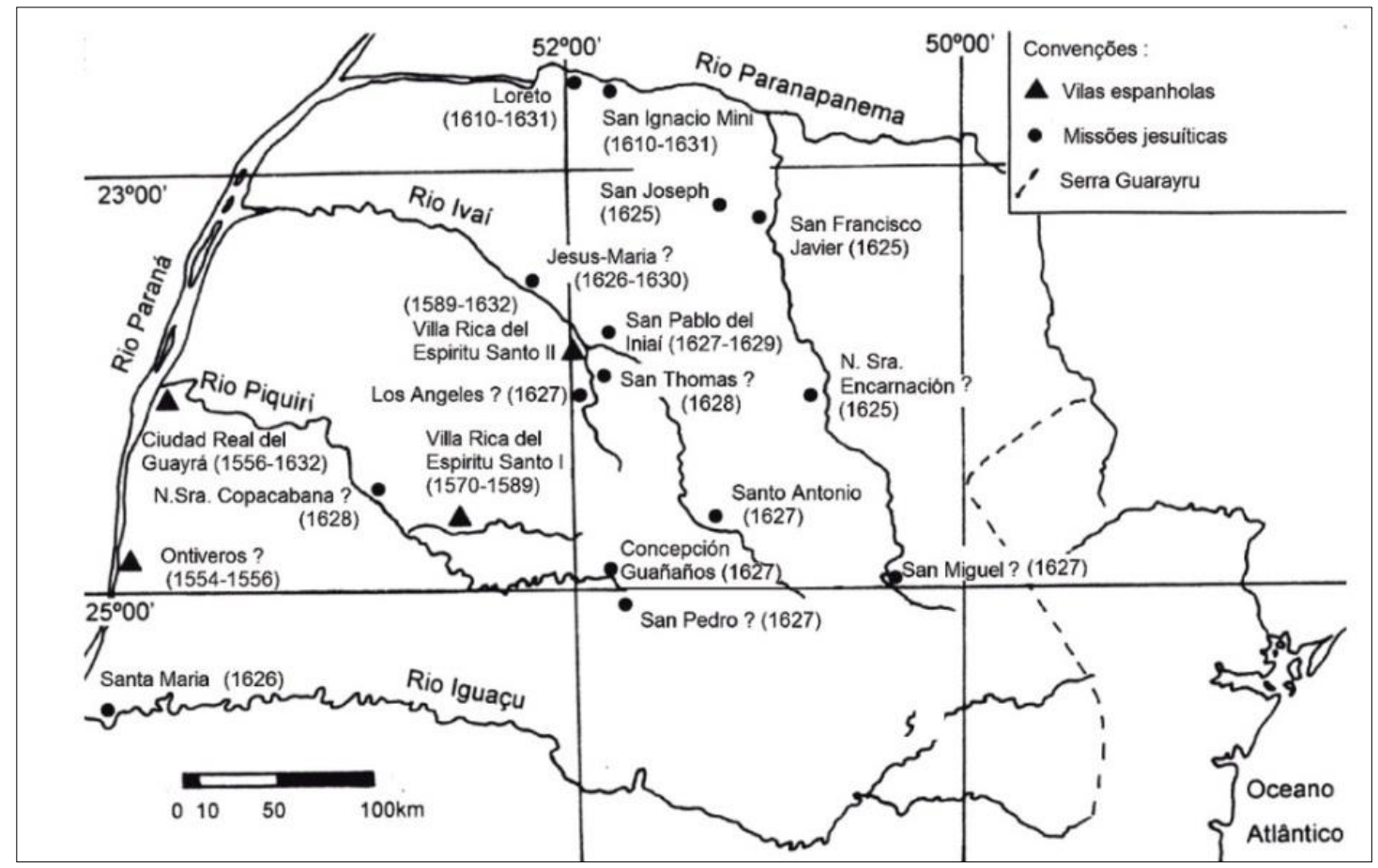

Fonte: Parellada (2014, p. 30).

Nos povoados constituídos majoritariamente por indígenas, logo os espanhóis e seus descendentes euroamericanos aprenderam a preparar e a tomar gosto pelo consumo da bebida, afastando-se, porém, do contexto ritualístico no qual era mais consumida. Mesmo assim, em meio a esses contatos interétnicos foi mantido seu consumo como elemento de sociabilidade e solidariedade entre as pessoas, dentre outras características. Dessa forma, ou mais ou menos assim, foi rapidamente difundida para outras áreas e somente na cidade de Assunção teriam sido 


\section{oficialmente consumidas de 14 a 15 arrobas de erva-mate no ano de 1620 (CORRÊA FILHO, 1925 e 1957).}

Figura 2: Representação cartográfica da área de ocorrência endêmica da erva-mate na bacia do Prata com a indicação da região correspondente a dos ervais nativos no antigo sul de Mato Grosso.

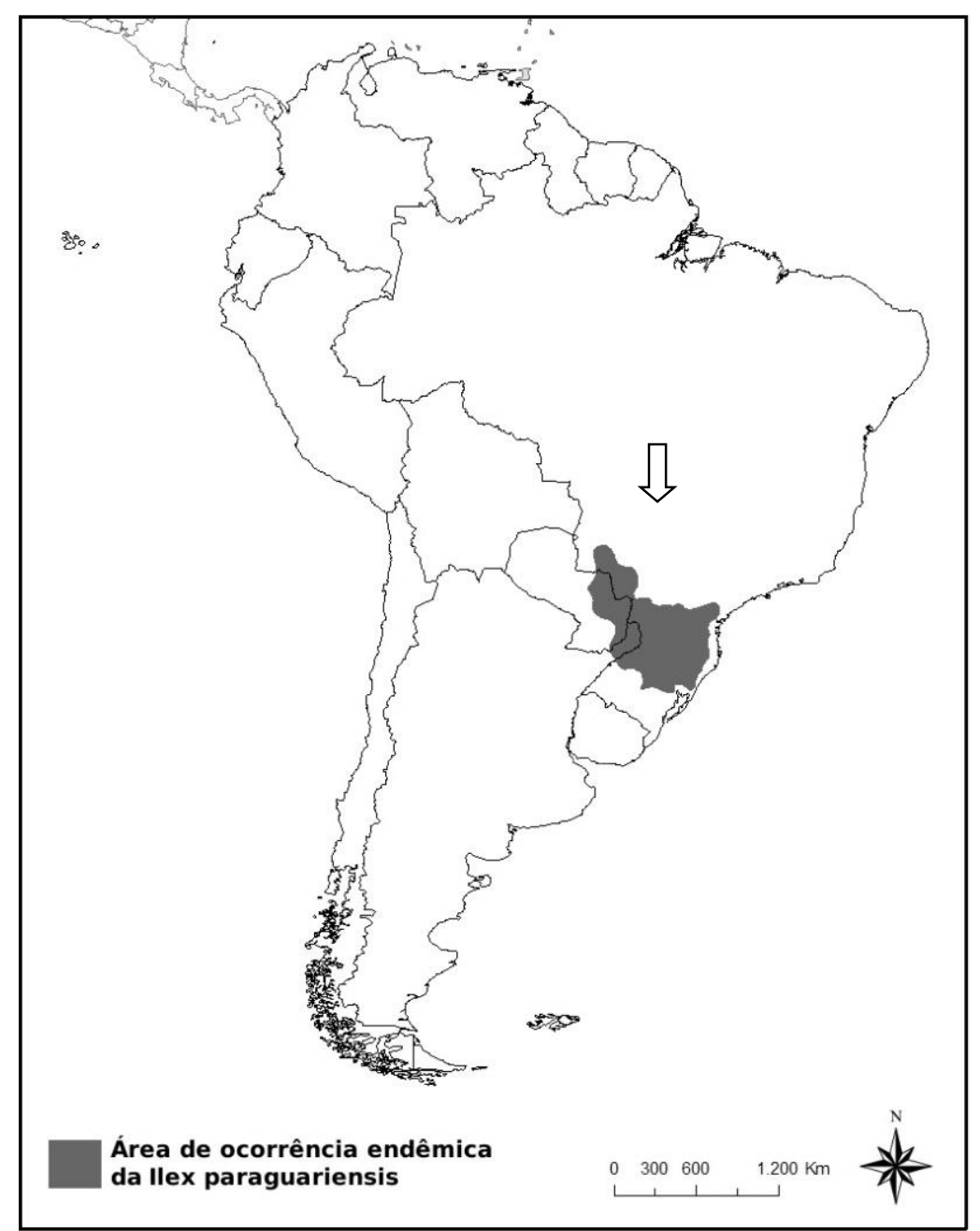

Fonte: Gerhardt (2013, p. 35 [ver também CORRÊA FILHO, 1957, p. 8]).

\footnotetext{
${ }^{6}$ Atualmente a erva-mate é consumida sob forma de chá ou ingerida como mate, assim chamada em castelhano e português quando tomada quente, como o chimarrão. Quando consumida fria, com água gelada ou fresca, é denominada de tereré, palavra onomatopéica de origem guarani. Em ambos os casos a bebida também é consumida em pequenos grupos, geralmente constituídos por familiares e amigos. Não raramente é preparada a partir da mistura de outras plantas à erva-mate, muitas delas refrescantes e medicinais. No caso específico do tereré, trata-se de uma bebida oficial considerada patrimônio cultural do Paraguai, onde há, inclusive, o Dia Nacional do Tereré, comemorado no último sábado de fevereiro, conforme a Lei $\mathrm{n}^{\circ}$ 4.261/2011. No Rio Grande do Sul também há um movimento pelo reconhecimento do chimarrão como patrimônio cultural imaterial. Significa dizer que a maneira como a bebida é consumida atualmente remete a processos históricos e socioculturais registrados na longa duração (BRAUDEL, 1990, p. 7-39), sobretudo no que se diz respeito a relações sociais mantidas no âmbito familiar e doméstico, e não, necessariamente, em termos de estruturas de pensamento.
} 
No começo do século XVII comerciantes de diversas regiões da América do Sul sob domínio espanhol já se deslocavam ao Guairá em busca da erva-mate. A rápida difusão do consumo da planta em amplos setores da população colonial exigiu a organização da produção para atender a um mercado em formação e crescimento. Em princípio os colonos não encontraram grandes dificuldades para implementar a exploração desse e de outros alimentos na região. Isso porque se estabeleceram em territórios ocupados por povos indígenas agricultores, onde havia solos de boa qualidade e extensos ervais nativos. Ali contavam com a exploração do conhecimento e da mão de obra de cerca de 4 mil indígenas, os quais eram obrigados a trabalhar nas plantações, extração e preparo da erva (GADELHA, 1980). Nesse período haveria pelo menos 40 mil índios na região, a maioria pertencendo a comunidades linguisticamente guarani e ainda não incorporadas diretamente à economia colonial (NOVAES, 2004).

Com a organização da produção em moldes comerciais ao longo dos seiscentos, o consumo se estendeu às margens do Prata, transpôs os Andes, chegou às regiões mineiras de Potosí e até ao Chile, Peru e Equador. Nesse período a erva-mate aparece entre os embarques de produtos realizados desde Assunção, sendo embalada em cestos diretamente ligados à maneira indígena de transportá-la. Por isso a extração da planta tornou-se a atividade econômica colonial mais importante na Província do Guairá, bem como uma fonte de recursos à Real Fazenda. A contínua ampliação do mercado consumidor tornou a exploração econômica do produto mais rendosa, enriquecendo muitos colonos espanhóis no Paraguai.

À medida que crescia o comércio da erva-mate era necessário, pois, aumentar sua produção, o que implicava na exploração de um maior número de indígenas, geralmente feita por meio da violência: mortes, rapina, roubo de pessoas etc. (CORTESÃO, 1951). Desde os primeiros anos dos seiscentos há registros de que os nativos passaram a se rebelar contra o domínio espanhol em todas as áreas onde a erva era explorada dessa maneira. Chegaram a causar prejuízos à coroa espanhola, como, por exemplo, com a destruição de lavouras oficiais. Em represália, os espanhóis empregaram de maior força para consolidar a hegemonia na 
região. No entanto, os confrontos com os indígenas no Guairá também provocaram muitas baixas nos exércitos a serviço da Espanha, sendo que nessas escaramuças houve a perda de uns 500 homens (GARAY, 1896). Do outro lado, o dos nativos, também houve muitas perdas, mas não há registros apurados sobre isso, principalmente diante das epidemias e não apenas por conta dos conflitos armados diretos.

Diante das reações indígenas e do temor que tomou conta de muitos espanhóis, dentre outros motivos, o governador do Paraguai, Hernando Arias de Saavedra, mais conhecido como Hernandarias, encaminhou pedido ao rei da Espanha para que fossem enviados sacerdotes à região. A ideia era que eles pudessem quebrar a resistência dos índios tidos como insubmissos, algo que demandaria o trabalho de catequese e evangelização: "Viendo con esto que no conseguiría sino muy difícilmente sobjuzgarlos por la fuerza, creyó conveniente usar las armas de la persuasión religiosa [...]" (GARAY, 1896, p. 86).

Neste contexto colonial, em 1609 foi fundada a Província Jesuítica do Paraguai, cuja área sob jurisdição religiosa compreendia, grosso modo, o antigo Vice-Reinado do Prata e os atuais territórios do Paraguai, sul da Bolívia, Uruguai e parte do Brasil (Rio Grande do Sul, Santa Catarina, Paraná e parcela de Mato Grosso do Sul e São Paulo). Logo de início os religiosos ali fundaram em torno de 13 reduções, localizadas no atual oeste do Paraná e proximidades da Ciudad Real del Guayrá.

A presença de sacerdotes da Companhia de Jesus gradualmente transformou o território em um campo de acirradas disputas entre colonos assuncenhos, bandeirantes, indígenas (a maioria linguisticamente guarani) e jesuítas, cada qual com interesses distintos. Os conflitos começaram a partir da instalação das reduções e à medida que os padres passaram a defender interesses que conflitavam com os daqueles que queriam apenas explorar a mão de obra indígena, inclusive por meio da escravidão, como no caso dos bandeirantes de São Paulo (MONTEIRO, 1994; LANGER, 2005). O conflito entre forças antagônicas teve desfecho final com a expulsão dos jesuítas dos domínios da Espanha em 1767. 
Figura 3: Representação cartográfica da área que grosso modo corresponde à antiga Província Jesuítica do Paraguai.

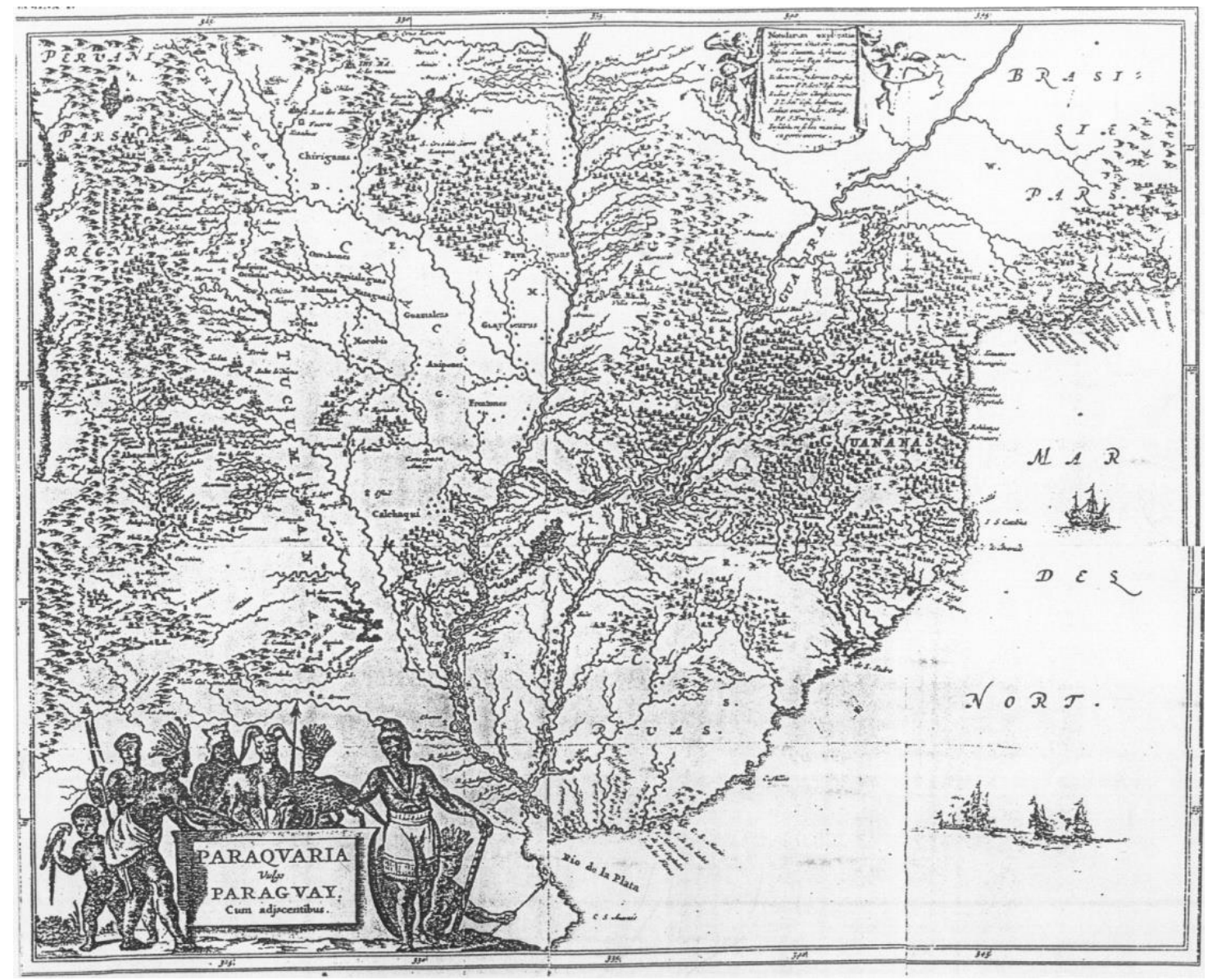

Fonte: Wilde (2007, p. 2).

Desde os primeiros anos os padres se colocaram contra o trabalho obrigatório que os nativos desenvolviam nos ervais: a encomienda e o serviço pessoal. Após percorrerem os assentamentos indígenas em meio às florestas, serras e povoados coloniais no Guairá, passaram a conhecer a região e diversas comunidades indígenas. As andanças permitiram, ainda, que os religiosos definissem estratégias para o trabalho de catequese e evangelização.

Na carta ânua do padre Nicolau Duran, de 1626/1627, consta o registro do uso generalizado da erva-mate fora do território paraguaio. No documento ele ainda explica que o uso da planta estimulava o apetite daqueles que a consumiam, levando-os aos prazeres alimentares, ou seja, ao pecado da gula. Também diz sobre a violência ligada à exploração 
do trabalho dos indígenas na extração e preparação da erva-mate no Guairá, onde havia iniciado o trabalho missionário.

[...] haze lastima el contarlo, deve cada indio dos meses de travajos y le hazen servir dos o 3 años por fuerqa fuera de su casa sin premio ninguno, y quando mucho le dan dos baras de lienzo a cada uno. los españoles venden esta hierba molida a los españoles mercaderes que vieen hasta el dicho puerto a trueque de lienzo y paño, sombreros y otras cosas necesarias, y acontece dar dos mil libras de hierva por un vestido de paño ordinario y 100 por un sombrero, el uso de esta tierra es que todos los españoles hombres y mugeres y todos los indios beven estos polvos en agua callente con que truequen todo lo que tienen en el estomago cada dia una y dos vezes. quando no tienen con que comprarla dan sus calzones y frezadas, y uvo muger que quito las tejas del texado por hierva en que dizen que consiste su salud en tanta forma que quando les falta la hierva desfallecen y dicen que no pueden vivir; todos los indios la toman antes que amanezca y todas las vezes que la tengan, cuando travajan, aunque no coman con sola hierva se sustentan y se avivan sus fuerzas para travajar de nuevo, como yo le visto en los bogadores de las balzas este vicio ha condido fuera del Paraguay a las prov.as del rio de la plata, Tucuman. Chile y aun ha llegado a Potosí y al Piru, donde vale quatro pesos la libra de la hierva, valiendo donde se coja medio real, esta hierva haze a los hombres araganes y glotones y la virtud de ella deve ser mas imaginación que verdad. Como los padres pues no quieren confesar los españoles, que tienen los indios tanto tiempo en este travajo, y como no aiudan a estas violencias que les hazen por esso les persiguen, y como los grandes participan de estas grangerias, muchas vezes crecen los testimonios que nos levantan y nos dan mucha ocasion de merecer (Carta Anua do padre Nicolau Duran 1626/1627 apud CORTESÃO, 1951, p. 217).

O padre Antonio Ruiz de Montoya, missionário no Guairá como Duran, também denunciou os maus tratos a que os índios estavam submetidos:

O trabalho naquela erva tem consumido a muitos milhares de índios. Sou testemunha ocular quanto à existência naqueles matos de ossários bem grandes de índios. Tal aspecto dói à vista, e quebranta o coração o 
saber - se que a maioria morreu pagã, andando perdida por aquela mataria em busca de sevandijas, sapos e cobras. E como nem sequer encontraram isso, bebe muito daquela erva, inchando-se Ihes os pés, as pernas e o ventre, mostrando seu rosto apenas, ossos e a palidez a figura da morte (MONTOYA, 1985, p. 41).

A situação impressionou negativamente os religiosos que por lá estiveram e testemunharam as condições em que a produção era organizada. Por conta do trabalho nos ervais, os nativos ficavam por longos períodos afastados de suas famílias, situação esta que afetava a economia e a abalava a própria organização social das comunidades. Na interpretação dos padres, a situação ainda não permitia a educação sistemática para sua evangelização e "salvação". Além disso, à época foi atribuída àquela bebida uma série de efeitos nocivos à saúde, como, por exemplo, que seu uso levaria à depravação dos costumes devido a supostos efeitos afrodisíacos da planta. Montoya chegou a afirmar que os nativos não poderiam continuar utilizando uma bebida que seria recomendada pelo demônio:

Digo q. con todo cuidado he buscado su origen entre Indios de 80 y 100 años y he sacado por cosa averiguada q. en tpo. q. estos viejos eran moços no se bevia, ni aun se conecía, sino de un gran hechicero o mago qe. tenia trato con el demonio, el cual de la mostro y dixo q. cuando quisiese consultarle beviesse aquella yerua y asi hizo y de su enseñanza otros qe. En nuestros dias hemos conocido y comunmente los hichizos qe. hazen llevan desta yerua. Dieron en usarla los Indios viejos, pero con moderacion (MONTOYA, 1639, p. 42).

Com a oposição inicial dos padres ao uso da planta, circularam versões e denúncias dos malefícios da bebida. Consequentemente, houve reações de autoridades coloniais que tentavam proibir o seu consumo, em atenção a orientações religiosas. Segundo Gadelha (1980, p. 164), no ano de "1596, atendendo a pedido do Procurador Alonso de La Madrid, Hernandarias" assim determinou:

Que nadie en adelante fuese ni enviase indios á hacer hierba á ninguna parte donde la haya ni la traigan ni traten ni contraten so pena de pérdida toda la hierba que 
se ha de quemar en la plaza pública; y el que la metiere y quisiere meter en la ciudad, como se prenda incurra en cien pesos de multa para gastos de guerra y denunciador. Y en la misma pena incurra cualquiera persona que la comprare y vendiere y á más serán castigados gravemente como inobedientes á la justicia Real y como procuradores de las ofensas de Dios y del Rey e del bien público. Y cualquiera persona, de cualquiera estado y condicion que sea / que beba hierba en público ó en secreto, incurra por la primera vez em 10 pesos de multa y en 15 días de carcel pública y en adelante sean castigados con graves penas (ARIAS DE SAAVEDRA, Hernán - "Ordenanzas sobre la hierba..." In: AGUIRRE, 1948, p. 360-361 apud GADELHA, 1980, p. 164).

O próprio Hernandarias, quem visitou as áreas de exploração da erva-mate, repudiou as formas de trabalho ali impostas e manifestou preocupação quanto ao consumo do produto, conforme explica o cônego João Pedro Gay:

Visitó la provincia con singular aceptacion, inspirando en los españoles conmiseración con los indios, navegando al puerto de Buenos Aires, descubrió en los remeros una talega de Yerba del Paraguay, que ellos llaman en su idioma Caa, que se empezó a beneficiar durante su gobierno, y aunque por entonces disimuló, saltando en tierra, quemó en publica Plaza la talega, diciendo à los indios: "no extrañéis esta demonstración, porque à ella me mueva grande amor que os profeso, pues oigo, me dice presagioso el corazon, que esta yerba será la ruina de vuestra nacion" (GAY, 1942, p. 27).

Apesar das proibições iniciais terem contribuído para diminuir a intensidade da exploração da erva, logo os sacerdotes e as autoridades governamentais perceberam a importância que os nativos e a crescente população mestiça davam à bebida. A situação foi mais bem notada à medida que expandia o seu consumo e crescia sua importância econômica na província. Somou-se a isso o fato de ela também poder desempenhar importante papel no combate ao consumo de bebidas alcoólicas e à embriaguês. Portanto, rendendo-se à exploração dos ervais nativos ainda no início do século XVII, os religiosos da Companhia de Jesus começaram a organizar a produção comercial ervateira nas 
reduções situadas na Serra de Maracaju e no Guairá. Com toda a produção feita dentro e fora das reduções, o Paraguai tornou-se o principal fornecedor de erva-mate na bacia platina.

No decorrer dos anos houve o aprimoramento das técnicas de produção e o resultado disso foi um produto de melhor qualidade e maior aceitação no mercado consumidor, constituído por folhas pequenas e menor quantidade de nervuras e galhos. A erva-mate produzida nas reduções também era comercializada pelos próprios padres, os quais evitavam o envolvimento dos nativos missioneiros com os encomenderos espanhóis e mestiços. Só a produção dos religiosos no ano de 1620 foi em torno de 50 mil arrobas, das quais 10 mil foram vendidas em Assunção e as outras 40 mil seguiram para os mercados de Santa Fé e Corrientes.

Posteriormente, com a expulsão dos jesuítas dos domínios da Espanha, em 1767, ocorrido na época do reinado de Carlos III, houve o desmantelamento das reduções. Consequentemente foi registrada a diminuição da produção ervateira no Guairá e em outras regiões onde a Companhia de Jesus atuava. Mesmo assim, o Paraguai continuou por anos sendo o principal produtor de erva-mate na região platina.

\section{Da independência do Paraguai e do Brasil ao antigo sul de Mato Grosso}

Após conseguir a independência, em 1811, o Paraguai passou a perder parte de seu mercado externo para a erva-mate produzida no Brasil. Isso teria ocorrido por conta da política adotada no governo de José Gaspar Rodríguez de Francia (1811-1840), cujo objetivo era fortalecer a autonomia do país, conservando-o, porém, menos aberto à exterioridade do ponto vista econômico (BANDEIRA, 1998). No entanto, no decorrer do século XIX, especialmente durante o governo de Carlos Antonio López (1840-1862), o país consolidou a condição de maior produtor da erva. Ao mesmo tempo recuperou o mercado consumidor externo e seguiu rivalizando com a produção brasileira. Sobre o assunto, assim escreveu, em 1849, o botânico Amado Bonpland, estudioso da planta, em carta endereçada ao referido presidente: 
Hoy el Brasil se encuentra en una posición de tal modo ventajosa, que podría fabricar yerbas de mate que serian preferidas a las del Paraguay. En este caso supuesto y verosímil el Brasil aumentaría sensiblemente la renta en este ramo agrícola (BONPLAND, 1849 apud WHIGHAN, 1991 , s. p.).

Entre $1^{\circ}$ de junho de 1857 e 30 de junho de 1858 , o Rio Grande do Sul vendeu à Argentina, pelo Porto de Itaqui, 1.324.593 quilos de ervamate. Esta quantidade, somada às remessas feitas ao Uruguai, oficialmente 1.923.593 quilos, alcançaram o total de 3.248.186 quilos. As exportações paraguaias, por seu turno, no montante de 985.274 quilos, em 1854, saltaram para 1.436.295 quilos, em 1857, e depois para 2.000.737 quilos, em 1860 (BANDEIRA, 1998)7. Com recursos gerados pelo comércio o governo paraguaio estabeleceu novos caminhos para 0 país: estimulou a instrução formal, impulsionou a construção de obras públicas, lançou as bases da siderurgia nacional e adquiriu vapores e máquinas. Não obstante, se por um lado o crescimento das exportações paraguaias trouxe resultados positivos para sua economia, por outro tencionou as relações com um Brasil que perdia espaço no mercado externo ervateiro.

O tencionamento acontecia praticamente desde a independência do Paraguai (1811) e mais tarde do Brasil (1822), quando República e Império, respectivamente, passaram a discutir a definição das fronteiras entre os dois jovens Estados-nações. O governo brasileiro manifestava amiúde preocupação com a integridade de seus territórios a oeste e mantinha conversações sobre o assunto com o governo paraguaio.

O governo de Carlos Antonio López não se negava a abrir a navegação do Rio Paraguai em seu país para os navios brasileiros, mas em contrapartida pleiteava um tratado que garantisse segurança às suas fronteiras. O governo do Brasil, por sua vez, considerava o Rio Apa como limite territorial, enquanto que o Paraguai tinha como divisa o Rio Branco. Se conseguisse abrir o Rio Paraguai ao comércio internacional, o Brasil poderia dinamizar o comércio fluvial, inclusive dando início a um maior aproveitamento dos ervais nativos existentes na porção meridional da

\footnotetext{
${ }^{7}$ Os dados aqui apresentados são oficiais e não registram, obviamente, os contrabandos da erva-mate que havia de um país para outro, como apontado por González Labale (1996).
} 
então província de Mato Grosso. Com isso também ofereceria uma concorrência à altura da própria produção ervateira no Paraguai.

Como a disputa não foi resolvida diplomaticamente a contento das partes, a questão territorial foi ajuntada a outros motivos que levaram à guerra entre o Paraguai e a Tríplice Aliança (1864-1870). Este conflito bélico platino teve consequências nefastas à economia paraguaia e mudou a fisionomia político-territorial do antigo Mato Grosso, palco de muitas batalhas.

Com o fim da guerra, o Império não demorou a definir e adotar medidas para dinamizar a incorporação de Mato Grosso ao mercado e ao projeto civilizador nacional. Criou condições para o investimento produtivo e para isso acionou mecanismos legais, como a Lei de Terras de 1850 , a Lei $n^{\circ} 601$, com vistas à colonização, inclusive por meio do arrendamento e venda de terras devolutas. Isso tudo ocorria em uma região ocupada por vários povos indígenas, alguns dos quais bastante populosos, como os Guarani e Kaiowá estabelecidos na parte mais austral da província. Era imperioso para o Estado brasileiro ocupar aquela área com população não índia ou "branca", organizar a produção em outros padrões, proteger as fronteiras com novos postos militares e recuperar as fortificações danificadas durante a guerra. À época as autoridades imperiais condenavam a facilidade com que as tropas paraguaias invadiram o antigo sul de Mato Grosso, inicialmente em fins de 1864, onde ficaram por dois longos anos. Por estes e outros motivos passaram a desenvolver projetos para incorporar aquela região fronteiriça ao território nacional. As perspectivas de desmembramento do Brasil mais uma vez inquietavam os dirigentes do país, cujo assunto era insistentemente mencionado no exterior (QUEIROZ, 1997).

No início da década de 1870 alguns projetos eram debatidos nos grandes centros para tirar o antigo sul de Mato Grosso de um suposto isolamento. O primeiro deles era a construção de uma estrada de rodagem que ligaria o porto de Sete Voltas à vila de Miranda. A ideia era facilitar o transporte entre as bacias dos rios Paraná e Paraguai, estabelecendo maior ligação fluvial entre as províncias de Mato Grosso e São Paulo. Também surgiram novos projetos de ligação ferroviária com o litoral brasileiro. Os projetos buscavam equacionar problemas relativos às vias de comunicação, cuja precariedade ficara registrada no fracasso 
de uma expedição enviada para expulsar os paraguaios da área durante a guerra (QUEIROZ, 1997). Neste contexto a região era amiúde apresentada com vazio demográfico, lugar de barbárie e sertão ermo longínquo da civilização ocidental (ver GALLETI, 2012). Por isso havia certa invisibilidade quanto à presença de comunidades indígenas no lugar, por vezes apontadas como selvagens e atrasadas, embora também citadas como mão de obra a ser empregada na economia regional. Igualmente tinha pouca visibilidade a presença de não indígenas posseiros de terras na área, geralmente percebidos como integrantes de um banditismo social (CORRÊA, 1995, 1999; BRAND, 1997; GUILLEN, 1999).

Uma das principais medidas adotadas pelo governo imperial foi criar estímulos à economia mato-grossense, permitindo o florescimento do comércio e a hegemonia exercida pelo porto de Corumbá. Esta cidade está localizada à margem esquerda do Rio Paraguai, na região do Pantanal, e à época estava ligada a vários centros platinos, bem como à Europa e outras partes do mundo. Neste sentido, segundo analisaram alguns autores, o capital e o trabalho afluíram para o antigo sul de Mato Grosso segundo a rota dos vapores, em um movimento que partia de Buenos Aires e Montevidéu, passando por Assunção, rumo a Corumbá (ALVES, 1984). Embora extremamente importantes, as hidrovias platinas foram vistas por autoridades imperiais com muita reserva, pois temiam que fossem interrompidas ao arbítrio dos países vizinhos (QUEIROZ, 1997).

Neste contexto prosperou a exploração econômica dos ervais nativos naquela região fronteiriça com o Paraguai. Trata-se, como dito amiúde, do lugar onde à época já existiam muitas comunidades guarani e kaiowá, as quais tinham a posse de um grande território, mas não possuíam títulos de propriedade das áreas que ocupavam. Por isso suas terras foram declaradas como devolutas pelo Estado brasileiro. Sendo assim, o governo central entendia que poderia arrendá-las e vendê-las a terceiros ou transferi-las a governos municipais e provinciais ou estaduais. Este entendimento, contudo, em certo sentido contrariava a própria Lei de Terras de 1850, que em seu Art. 12 previa a destinação de áreas para os indígenas: 
Art. 12. O Governo reservará das terras devolutas as que julgar necessarias: 10, para a colonisação dos indigenas; 20 , para a fundação de povoações, abertura de estradas, e quaesquer outras servidões, e assento de estabelecimentos públicos; 30, para a construção naval (BRASIL, 1850 - grifos nossos).

Posteriormente, nos primeiros momentos da República, muitas terras devolutas foram transferidas para o governo de Mato Grosso. Este, por sua vez, apoderando-se de grandes extensões e desconsiderando a mencionada norma, seguiu repassando territórios indígenas a terceiros. Quando os novos proprietários ou seus sucessores tomaram posse das terras, muitos promoveram esbulho contra os nativos e posseiros pobres não índios que ali viviam. Isso ocorreu com mais frequência após a estruturação das fazendas, quer dizer, posteriormente à exploração do trabalho indígena na derrubada da mata, formação de pastagens, abertura de estradas etc. Não raramente as expulsões contavam com a ação de jagunços e até mesmo com o protagonismo de agentes do Estado nacional: forças policiais, servidores da agência indigenista oficial etc. Deste processo, grosso modo compreendido entre a segunda metade do século $X I X$ e a primeira do $X X$, teve origem parte significativa da propriedade privada da terra e da estrutura fundiária dos atuais estados de Mato Grosso e Mato Grosso do Sul (BRAND, 1997; EREMITES DE OLIVEIRA e PEREIRA, 2009 e 2012 ; FERREIRA, 2007; CAVALCANTE, 2013 ).

Após a guerra foi constituída uma comissão mista demarcatória dos limites territoriais entre o Brasil e o Paraguai, cujos trabalhos foram realizados de 1872 a 1874 . Do lado brasileiro a comissão foi composta por quatro militares: coronel de engenharia Rufino Enéas Gustavo Galvão, futuro visconde de Maracaju e posteriormente governador da Província de Mato Grosso (primeiro comissário), major Francisco Xavier Lopes de Araujo, depois barão de Parimã (segundo comissário) e capitães Guilherme Carlos Lassance (ajudante) e Joaquim de Oliveira Pimentel (secretário). Contava ainda com o apoio de 50 praças de infantaria e outros 10 de cavalaria, sob o comando do então major Antonio Maria Coelho, futuro barão de Amambaí e governador do Estado de Mato Grosso após a proclamação da República, em 1889. Este último militar conseguiu elevado prestígio após destacada atuação no conflito, especialmente durante o evento conhecido como a Retomada de Corumbá, em 13 de 
junho de 1867, quando as tropas paraguaias foram derrotadas e aquela cidade retornou aos domínios do Brasil. Estava incumbido, dentre outras coisas, de evitar qualquer agressão por parte dos indígenas aos militares. Do lado paraguaio fizeram parte três militares: capitão de fragata Domingos Antonio Ortiz (comissário), José Antonio Espinola (ajudante) e José Dolores Espinosa (secretário).

A um comerciante sulista pouco conhecido à época, Thomaz Larangeira, quem teria lutado na guerra e acompanhou os trabalhos demarcatórios da comissão, coube a função de fornecedor de víveres à expedição. Para isso contava com o auxílio de Francisco Mendes Gonçalves, com quem idealizou e executou a fundação da Companhia Matte Larangeira. Ao participarem dos trabalhos de demarcação desde as cabeceiras do Rio Apa até as serranias de Amambai e Maracaju, identificaram a existência de abundantes ervais nativos, alguns dos quais explorados por pequenos produtores independentes (JESUS, 2004; QUEIROZ, 2010b). Mais ainda, notaram a presença de várias comunidades indígenas que falavam a língua guarani e perceberam seu potencial enquanto mão de obra para uma futura produção ervateira em grande escala. À vista disso, registra-se outra vez a cristalina conexão existente entre a área dos ervais nativos, aqui percebidas como paisagens humanizadas ou florestas antrópicas, e o território dos povos Guarani e Kaiowá no extremo sul da província. Portanto, a área posteriormente concedida à empresa se sobrepôs desde o início a territórios indígenas (BRAND, 1993 e 1997; SILVA, 2005; BRAND et al., 2005; FERREIRA, 2007; CAVALCANTE, 2013).

Com a posse de Rufino Enéas Gustavo Galvão ao governo de Mato Grosso, Larangeira recorreu ao antigo chefe da comissão mista e articulou auxílio para obter a concessão da exploração dos ervais nativos. O pedido foi atendido e o próprio Galvão interferiu junto ao governo imperial para que Ihe fosse outorgada a concessão almejada. Enquanto aguardava a autorização para instalar uma companhia no Brasil, fundou, em 1877, uma empresa ervateira em Conceição, Paraguai, iniciando a produção. Esta situação denota a origem multinacional da companhia e a existência de uma rede de relações políticas que favoreceu o projeto ervateiro de Larangeira e aliados. Dela participaram veteranos da guerra e pessoas envolvidas nos trabalhos da comissão mista demarcatória, algumas das 
quais posteriormente agraciadas com títulos nobiliárquicos, dentre outras pessoas. Estava constituído, pois, um establishment ervateiro, aqui entendido como um grupo sociopolítico devidamente empoderado e capaz de manter certo controle e influenciar ações públicas e privadas em defesa de seus interesses em Mato Grosso e para além-fronteiras.

Figura 4: Representação cartográfica do território guarani e kaiowá em Mato Grosso do Sul, cuja área incide sobre a apontada na Figura 2 como sendo endêmica da erva-mate no estado.

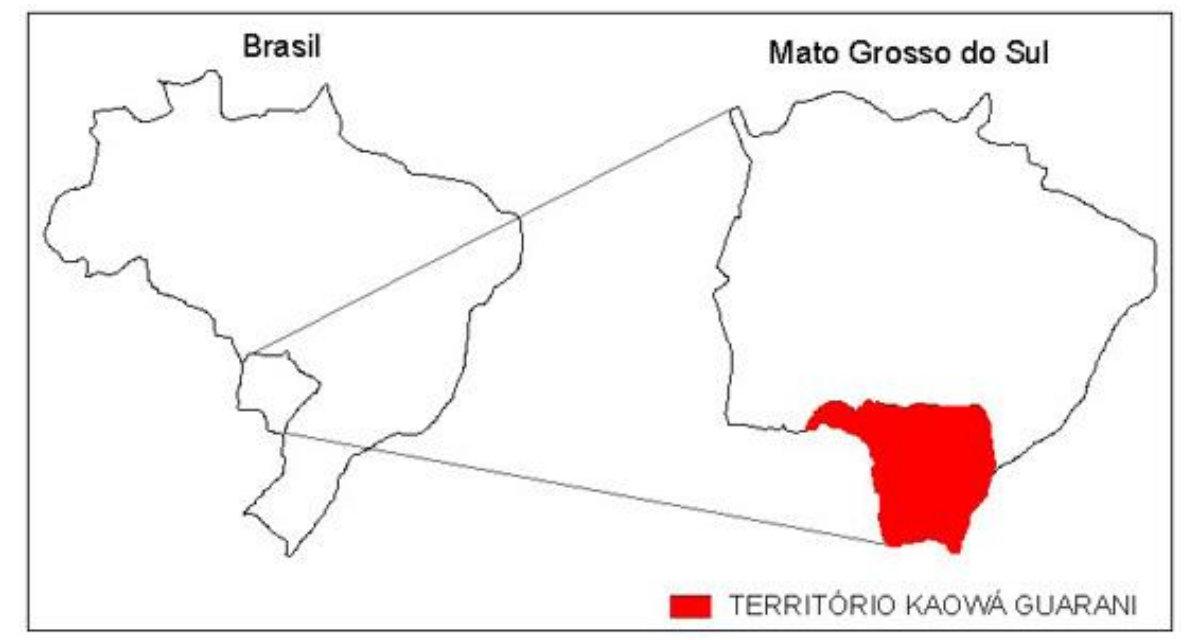

Fonte: Geoprocessamento do Programa Kaiowá Guarani, NEPPI, UCDB (2005, s.p.).

Pelo Decreto Imperial $\mathrm{n}^{\circ} 8.799$, de 9 de dezembro de 1882 , o governo central concedeu inicialmente a ele a permissão para explorar por dez anos os extensos ervais nativos encontrados em terras tidas como devolutas. Com a concessão outorgada, a sede da empresa foi transferida, em 1891, para a Fazenda Três Barras, à margem esquerda do Rio Paraguai, na região chaco-pantaneira do Brasil. Ali houve a fundação de um porto para a exportação de erva-mate cancheada, isto é, seca, triturada e pronta para o beneficiamento final. O local foi denominado Porto Murtinho em homenagem ao influente político liberal Joaquim Murtinho, que mais tarde foi ministro da fazenda no governo Campos Sales (1898-1902) (ver QUEIROZ, 2010a). Assim foi criada a Empresa Matte Larangeira, posteriormente rebatizada de Companhia Matte Larangeira, cuja sede anos depois foi transferida para a Fazenda Campanário, próxima à atual cidade sul-mato-grossense de Caarapó 
(CORRÊA FILHO, 1925, 1957 e 1969; ARRUDA, 1997; BRAND, 1997; VILELA DA SILVA, 1997; JESUS, 2004; FERREIRA, 2007).

Em 1892, dez anos após a primeira concessão e já não mais no Império e sim na República, a corporação teve a autorização renovada pelo governo. Em 1894 a concessão foi ajustada em Cuiabá, "mediante contrato de arrendamento de vasta área, estimada em 1.600 léguas quadradas, do Ivinheima para o sul" (CORRÊA FILHO, 1969, p. 591). Os acordos foram selados a partir de uma articulação política entre a empresa e o governo estadual:

Uma das principais características da exploração ervateira, nos territórios do Mato Grosso, foi a estreita vinculação entre a esfera pública e a esfera privada, entre governo e empresa. Tal era a proximidade dos personagens envolvidos que é difícil estabelecer os limites entre uma esfera e a outra, onde começavam os interesses de um e terminava o do outro (ARRUDA, 1997, p. 29).

O referido autor cita Virgílio Corrêa Filho para corroborar sua análise:

O contrato ajustado em Cuiabá, a 2 de agôsto de 1894, levou as assinaturas do Dr. Manoel Murtinho, como Presidente do Estado; Dr. Francisco Murtinho, representante do $\mathrm{Dr}$. Joaquim Murtinho, Presidente da Empresa arrendatária. A transação processou-se entre os três irmãos que procediam sempre de harmonia (CORRÊA FILHO, 1969, p. 619).

Constata-se, portanto, que o establishment ervateiro também era fortalecido por relações de parentesco e valia-se de expedientes dos mais complexos para defender seus interesses junto aos governos. Por isso a Companhia Matte Larangeira foi considerada como um Estado dentro do próprio Estado, conforme apontam Corrêa Filho (1957, p. 60-66) e Arruda (1997, p. 29-46), ou ainda como um enclave, como sugere Queiroz (2010b, p. 17). De todo modo, o fato é que as condições eram bastante favoráveis ao projeto de Thomaz Larangeira e aliados: milhões de hectares de terras com grande quantidade de ervais nativos, rede hidrográfica favorável à comunicação fluvial, abundante quantidade de 
mão de obra de indígenas conhecedores da planta e da região e apoio político nos governos de Mato Grosso e central. O empreendimento ainda contava com a desorganização da produção ervateira no Paraguai, consequência da guerra, o que em um primeiro momento diminuiria a concorrência no mercado externo, onde a erva-mate era um produto bastante procurado.

Até 1902 a empresa funcionou com o nome de Companhia Matte Larangeira; posteriormente, sua sucessora, a Larangeira, Mendes \& Companhia, manteve o monopólio da exploração da erva-mate em Mato Grosso, bem como suas ramificações na Argentina e Paraguai. Em 1916 a área arrendada foi diminuída para uns 2 milhões de hectares. Além desses terrenos devolutos, a última dessas empresas dispunha de 271.026 hectares em 1923, adquiridos através da compra de terras nos municípios de Bela Vista e Ponta Porã (ALVES, 1984). Com o arrendamento ela seguiu no controle daquelas terras até parte da década de 1940, mas não sem disputá-la, desde o início, com pequenos produtores independentes e outras pessoas e grupos (JESUS, 2004; QUEIROZ, 2010b). A firma entendia ter o direito de expulsar posseiros estabelecidos nas áreas arrendadas e para isso mantinha uma espécie de polícia particular sob seu comando. Dessa maneira contribuiu diretamente para a usurpação de terras indígenas, bem como para a promoção da violência contra indivíduos e coletividades que pudessem significar perigo ou obstáculo a seu projeto hegemônico. Este é o caso dos gaúchos que aos poucos migraram para a região a partir do final do século XIX, estabelecendo-se nos municípios de Bela Vista e Ponta Porã, onde muitos "não desejavam tornarem-se empregados da Matte, mas sim proprietários independentes" (ARRUDA, 1997, p. 48). Dito de outra maneira, embora fosse o maior empreendimento ervateiro na região desde a década de 1880, a empresa não conseguia manter total vigilância e exclusividade sobre vastas extensões. No decorrer dos anos, especialmente a partir das três primeiras décadas do século XX, essas áreas passaram a ser preteridas por outras pessoas e grupos que se estabeleceram em sua área de influência. Não se deve confundir, portanto, "a história da economia ervateira sul-mato-grossense com a história da empresa, como se fossem ambas uma só e mesma coisa" (QUEIROZ, 2010b, p. 6). 
Faz-se necessário, ainda, registrar que na historiografia brasileira até os anos 1990 era predominante a tese de que o ônus do trabalho nos ervais recaiu, sobretudo ou unicamente, nos ombros de trabalhadores paraguaios. Muitos historiadores entenderam que eles teriam vindo para o antigo sul de Mato Grosso após o fim da guerra, a partir das décadas de 1870 e 1880 , como se na época a população masculina fosse muito expressiva naquele país. Na verdade, o fato é que a mão de obra indígena era a maior força de trabalho ali disponível no início da produção ervateira. Somou-se a ela a contribuição de trabalhadores não índios provenientes de outros lugares. Esta interpretação é corroborada por estudos mais recentes, os quais foram elaborados a partir da análise de documentos do SPI - Serviço de Proteção aos Índios (1910-1967), além do registro, por meio da história oral, da memória social dos Guarani e Kaiowá que labutaram em condições análoga à escravidão nos empreendimentos ervateiros. Os trabalhos de Brand (1993 e 1997), Brand et al. (2005), Silva (2005) e Ferreira (2007), dentre outros, são exemplos de uma produção intelectual mais recente, inserida dentro de uma pujante tendência historiográfica em Mato Grosso do Sul e em outros estados: a história indígena (EREMITES DE OLIVEIRA, 2012b).

A percepção dos Guarani e Kaiowá na história da economia ervateira no antigo sul de Mato Grosso exige, com efeito, uma leitura a contrapelo das fontes escritas oficiais sobre a companhia. Em registros assim os trabalhadores indígenas falantes da língua guarani foram deliberadamente citados como paraguaios, quer dizer, inscritos na história como estrangeiros dentro de suas próprias terras. Esta foi uma estratégia relativamente bem-sucedida para produzir invisibilidade àqueles sujeitos, cujos direitos não eram respeitados e sua presença contrariava a tese de vazio demográfico na região. Inscrevê-los nos documentos oficiais contestaria ainda a tese do sucesso do projeto civilizador, concebido à luz de um grande empreendimento ervateiro, em uma região tida como sertão ermo e palco de uma grande guerra. Contudo, em meados do século XX um historiador brasileiro registrou que os primeiros trabalhadores da companhia eram índios e denunciou os maus tratos a que foram submetidos: 
Larangeira mobilizou cerca de três centenas de peões e auxiliares para a exploração concedida. Gizou planos de aproximação amistosa com os nativos, fomentando contatos que frequentemente teriam trágicos desenlaces. E ficariam sem estatística os sacrifícios recíprocos de peões e de silvícolas, desavindos em luta implacável, no silêncio das matas (ALMEIDA, 1951, p. 416).

Ademais, quando do término da guerra entre o Paraguai e a Tríplice Aliança, cerca de dois terços da população paraguaia tinha sido dizimada durante o conflito, conforme é amplamente conhecido na historiografia (WHIGHAM e POTTHAST, 1999; MORAES, 2000; ESSELIN, 2011 ; ESSELIN et al., 2012; etc.). De acordo com Efraim Cardozo:

El Paraguay quedo librado a su muerte. La parte más dura de la empresa de reconstruir el país recayó sobre las muyeres. Crearon un género de sociedad poligámica, revivencia forzada de las costumbres del siglo XVI, que permitió reponer rápidamente las perdidas demográficas. En esta nueva etapa, la tarea principal de los hombres fue la política. Se emprendió con entusiasmo la tarea de crear nuevas instituciones (CARDOZO, 1991, p. 121).

O naturalista Herbert $\mathrm{H}$. Smith, que esteve em Assunção na década de 1880, deixou registrada a situação apontada para dirimir eventuais dúvidas:

Todo o paiz está gafado pela pobreza. Os povoados com seus laranjaes sombrios e os morros umbrosos por traz são muito pittorescos; mas as casas são pequenas e esquálidas, e a gente miseravelmente destituída de recursos. Quasi não se vêem homens; a guerra tragou-os todos, e os rapazes que cresceram depois procuram empregos na cidade ou na labuta do rio. Agora os povoados têm quasi exclusivamente por habitantes mulheres e crianças. [...] Talvez a parte de Assunção que mais parece prosperar é o mercado, que achámos bem supprido de carne e vegetaes. Estava cheio de compradores e vendedores, na maior parte mulheres, vestidas de algodão branco e um lençol branco posto na cabeça e hombros, costume muito semelhante ao do sertão do Ceará e Pernambuco (SMITH, 1921, p. 231-232, - grifos nossos). 
$\mathrm{Na}$ época era pequena a população paraguaia que emigrou para o Brasil. Segundo o censo de 1872, havia 1.669 estrangeiros computados em toda a província de Mato Grosso. Deste total, 764 habitavam a região sul, dos quais 226 eram paraguaios, sendo 122 homens (101 solteiros, 18 casados e 3 viúvos) e 104 mulheres (93 solteiras, 5 casadas e 6 viúvas) (MATTOS, 1990). Além disso, após o termino da guerra as autoridades paraguaias trataram de criar uma legislação específica para impedir que os trabalhadores deixassem seus postos de serviço. O objetivo do governo era evitar uma nova sangria de braços para o país poder reorganizar a produção afetada pelo esforço de guerra: "[...] em 1871 fue aprobada una ley que prohíbia a los peones abandonar los yerbales sin autorización de los proprietários y estabelecer la penalidad de captura y multas si llegaban a escapar" (NICKSON, 1981, p. 3).

Os dados apresentados asseveram que a mão de obra indígena foi largamente explorada desde o início da Companhia Matte Larangeira, pois não havia tantos trabalhadores paraguaios ou nacionais a sua disposição. Também eram poucos os colonos de outras regiões do Brasil e estrangeiros na província de Mato Grosso nas décadas de 1870 e 1880, situação esta que inclusive preocupava as autoridades. Em vista disso, a solução encontrada foi explorar a força de trabalho dos índios. Até os canoeiros Guató, habitantes das áreas inundáveis do Pantanal, área distante daqueles ervais, foram indicados como úteis a fazendeiros em busca de mão de obra indígena:

[...] sendo de utilidade o chamar-se aldeamento os Índios Guatós que habitão nas margens do rio São Lourenço, onde vivem em pequenos grupos dispersos occupando-se da caça de que se subsistem, sendo que esses Índios que d'a muito se relacionão comnosco, dirigidos e aldeados por huma pessoa hábil podem se tornar úteis aos Fazendeiros d'aquella localidade [...] (SANTOS, 1885, s. p.).

O próprio presidente da província, em fala oficial na abertura dos trabalhos legislativos de 1878, fazia um diagnóstico da absoluta ausência do homem "civilizado" que entendia ser tão necessário ao processo de produção: 
Não há quem ignore que a causa da colonização e da catequese prende-se todo o futuro engrandecimento desta província. Na vastidão do seu território, cheio de immensos desertos, coberto de virgens florestas, onde até hoje o homem civilizado ainda não penetrou, a população rarêa tanto que esta quasi na razão de 1 habitante por légua quadrada. Sem braços que fertilizem o seo solo, aliás capaz de conter commodamente mais de cem milhões de habitantes, attentas as suas condições naturais, iguaes ou superiores aos mais fecundos paizes da Europa, sem braços, digo, como poderão ser aproveitadas as innumeras e inexhauriveis fontes de riqueza que aqui existem e que enchem de admiração os estrangeiros que as contemplão (PEDROSA, 1878, s.p.).

Nas últimas décadas do século XIX, quando deslanchava a produção ervateira, havia poucas esperanças das autoridades mato-grossenses em atrair imigrantes para colonizar a província, diferentemente do que ocorria em outras partes do país. A solução encontrada continuava a ser o aproveitamento do indígena. Ele deveria ser atraído para o aldeamento e lá evangelizado e preparado para ser integrado, na condição de aculturado, braçal e subalterno, à sociedade nacional. Além disso, ainda que em 1905 o governo contabilizasse uns 5 mil migrantes sulistas no estado, deve-se considerar que a maioria estava ali à procura de terras e não, por exemplo, em busca de emprego como mineiro ou trabalhador braçal nos ervais (ARRUDA, 1997). Por isso houve quem chegasse a disputar a posse de áreas com a própria empresa e, após o cancelamento da concessão, em 1949, com proprietários vindos de Minas Gerais e outros lugares. Foi mais ou menos assim o que aconteceu nas décadas de 1930, 1940 e 1950 na Colônia Penzo, gleba que deu origem ao município de Antônio João, na localidade conhecida como "Cabeceira do Bugre", na bacia do Apa, entre Bela Vista e Ponta Porã, fronteira com o Paraguai (EREMITES DE OLIVEIRA e PEREIRA, 2009, p. 61). Para lá foram muitos migrantes sulistas e alguns imigrantes, dentre outras pessoas. Não obstante esta situação, o fato é que naquela região fronteiriça já existiam várias comunidades kaiowá e alguns posseiros não índios, sendo que ambos eram agricultores e, ao que tudo indica, não trabalhavam nos ervais da companhia ou de produtores independentes. 
Dessa maneira, torna-se imperativo reconhecer que nas primeiras décadas da Companhia Matte Larangeira o trabalho braçal nos ervais foi realizado majoritariamente pelos Guarani e Kaiowá, embora nem todas as comunidades indígenas tenham estado diretamente envolvidas na economia ervateira. Esses índios foram submetidos a uma situação análoga à escravidão, tal como é compreendida atualmente. Nesta condição eram obrigados a trabalhar em todo o processo produtivo e esta prática de exploração da mão de obra nativa perdurou por muito tempo. Mesmo na década de 1920 os índios ainda representavam o maior contingente de trabalhadores em muitos campos ervateiros aproveitados pela empresa e por produtores independentes. A situação é descrita em um relatório de 1927, elaborado por Genesio Pimentel Barboza, funcionário do SPI, que observou a realidade in loco e fez a devida denúncia à direção do órgão indigenista:

Dest'arte o indio caiuás é, nos hervaes de Matto-Grosso, uma propriedade do hervateiro paraguayo, que sem nenhum escrúpulo o explora, moral e materialmente.

A proporção de índios caiuas empregados na elaboração da herva, sobre o operário, é, em média, de $75 \%$ na região de Iguatemi.

Em minha recente excursão ás aldeias da fronteira, visitei varios estabelecimentos hervateiros, verificando que a quantidade de indios que nelles trabalha é sempre superior ao trabalhador paraguayo (BARBOZA, 2003 [1927], p. 81 - grifos nossos).

À época, o SPI estava a assegurar oito áreas de uns 3.600 hectares para a formação de reservas indígenas no antigo sul de Mato Grosso. Para lá deveriam ser enviados os coletivos guarani e kaiowá que viviam na região dos ervais nativos e adjacências. Com isso foi criada a ideia de que lugar de índio é na reserva, isto é, em áreas oficialmente reservadas pelo Estado nacional para o aldeamento dos povos originários. No entanto, muitas famílias indígenas resistiram a esta imposição e permaneceram até parte da segunda metade do século $X X$ em pequenas extensões de seus territórios tradicionais, chamados tekohá, de onde acabaram sendo expulsas. Por este motivo, em pouco tempo, especialmente durante o declínio e fim da companhia, as terras indígenas existentes fora das reservas foram transformadas em propriedades privadas. Este é o vício na 
origem dos títulos de muitos imóveis existentes no atual Estado de Mato Grosso do Sul, conforme apontado em laudos periciais produzidos por determinação da Justiça Federal (ver EREMITES DE OLIVEIRA e PEREIRA, 2009 e 2012).

A situação apontada vai ao encontro da própria memória indígena sobre aqueles tempos, conforme explicou o kaiowá Nicásio Vasques, morador de Laguna Caarapã na década de 2000, que também foi mineiro nos ervais:

É com a família (...) era até 3 horas, 4 horas (da manhã) ia no mato, tirava, cortava com facão, né e aí juntava a erva, né, sapecava (...). É o índio naquele tempo sofria, levantava cedo, comia só cangica, mal e mal e já vai embora (...). A mulher do roçador levava almoço pra ele no mato, né, ia no mato cortar, sapecar erva, né (...), noite, 7, 8 horas chegava no rancho e dormia. 4, 3 horas já levantava outra vez (BRAND et al., 2005, p. 2).

Situação análoga foi registrada na mesma época pela professora Valdelice Verón, filha de Marcos Veron, cacique kaiowá assassinado em 2003 na Terra Indígena Takuara:

O meu avô trabalhou para a Cia Matte Larangeira muito tempo, sem receber o pagamento pelo serviço. Então, um dia ele decidiu voltar para o grupo de sua família, ele e a minha bisavó, e os filhos Antônio e Gregório Veron. Na hora do acerto, o administrador disse a ele que não tinha nada em haver, acertar a conta, pelo contrário que se ele e a turma dele saísse do trabalho seria um homem morto. Assim, meu bisavô decidiu ir embora. Sabendo disso o administrador mandou quatro capangas atrás deles, quando já estava amanhecendo eles saíram num cerrado e quando estava no meio do cerrado meu bisavô avistou os capangas. Percebendo que estavam sendo seguidos, escondeu os filhos Antonio e Gregório na mata e ele e minha bisavó continuaram a andar, mais alguns passos então os capangas atiram nos meus bisavó que morreram na hora (BRAND et al., 2005, p. 6 - grifos nossos). 
Conforme explicado ao longo do trabalho, à medida que a produção ervateira foi ampliada, a Matte Larangeira transformou-se em um grande império econômico e político. Por este motivo os trabalhadores alistados como mineiros nos ervais dificilmente conseguiam escapar de seu jugo. Os armazéns da empresa forneciam alimentos, roupas e demais produtos de que dependiam para a subsistência. Todas as despesas eram descontadas nos salários e, dessa forma, por mais que labutassem, não conseguiam quitar as dívidas cada vez maiores. Este tipo de exploração é chamado sistema de barracão, caracterizado pelo endividamento dos trabalhadores, os quais terminam por ficar presos aos patrões e, portanto, mantidos como que em cativeiro, sem a liberdade de ir e vir. Ademais, as condições de trabalho nos ervais eram muito precárias. Um dos aspectos mais desumanos dessa lida era o transporte do fardo de erva-mate, chamado raído, realizado pelo próprio mineiro, por vezes a pesar mais de 150 quilos. Soma-se a isso o fato de os trabalhos serem realizados em condições insalubres, onde, apenas para exemplificar, os mineiros eram obrigados a inalar fumaça durante o preparo da erva. Além do mais, moravam em ranchos precários e não ocasionalmente infestados de pulgas e carrapatos. Por isso poucos completavam cinquenta anos nos ervais; antes disso estavam velhos e esquálidos (DONATO, 1957).

Sobre o assunto, registram-se as palavras de um kaiowá chamado lapequino, que até a década de 1940 trabalhou nos ervais e depois, em 1948, no final da Companhia Matte Larangeira, foi morar na Reserva Indígena de Dourados:

Carregava até 150, 200 quilos. Porque eles entrava no mato, eles tinha que fazer picada. Não entrava nada. Eles tinha que trazer um raído de erva-mate (...) que tivesse dentro do mato eles carregava, eles colocavam aquele fardão, de 500 em 500 metros tinha um pau fincado no chão onde descansava (...). Por isso que a gente tem que tirar o chapéu pelos Kaiowá por que eles cooperaram... (BRAND et al., 2005, p. 3, destaques nossos).

Cumpre ainda citar parte da entrevista que João Vilhalba, ancião kaiowá da Aldeia Racho Jacaré que também foi mineiro nos ervais, com 80 anos em fins de 2004, concedeu a Eva Maria L. Ferreira: "Hum! Porque 
o patrício é de tudo, sabe, o Kaiowá Guarani é de tudo, parte da erva. Ele é mineiro, ele é barbakuazero, ele é seca erva, ele é lenheiro, é o Kaiowá é..." (FERREIRA, 2007, p. 10, destaques nossos).

No âmbito da história da Companhia Matte Larangeira, a situação apontada perdurou da inauguração até o encerramento de suas atividades (1882-1949). Neste período o percentual de trabalhadores indígenas variou em relação à totalidade de mineiros e outros braçais envolvidos nas primeiras etapas de produção da erva-mate cancheada. Exemplo disso era quando alguns nativos conseguiam se livrar do cativeiro e iam morar nas reservas criadas a partir da década de 1910. Naqueles espaços destinados aos índios havia um forte sistema de dominação imposto pelo SPI, missionários evangélicos etc., o que não atraía a muitos coletivos. Depois do fechamento da corporação, outros indígenas ainda continuaram a trabalhar nos ervais para produtores independentes até, pelo menos, a década de 1950. Trabalhar para ervateiros autônomos era algo que, aliás, ocorreu antes, durante e após o fim da empresa. De todo modo, torna-se plausível - e até mesmo irrefutável - o argumento de que trabalhadores guarani e kaiowá são sujeitos na história da economia ervateira na região.

\section{Considerações finais}

Durante grande parte do período colonial os espanhóis e seus descendentes euroamericanos exploraram os ervais nativos na região platina, sobretudo na antiga Província do Guairá. Trata-se de áreas localizadas em territórios ocupados por povos indígenas falantes da língua guarani, chamados genericamente de guarani na historiografia e na literatura de natureza arqueológica, etnológica e etno-histórica. Em regiões assim a presença da erva-mate, uma planta semidomesticada, está originalmente associada a paisagens humanizadas, isto é, a florestas antrópicas. Ali a economia ervateira prosperou por conta, também, da exploração do território, da mão de obra e do conhecimento de milhares de indígenas, cujos antepassados mais antigos estabeleceram-se na bacia hidrográfica do Rio da Prata há pelo menos 2 mil anos. 
Posteriormente, no primeiro quartel do século XIX, ex-colônias europeias conquistam a independência e transformaram-se em jovens Estados-nações com vastos territórios naquela parte da América do Sul. A partir de então o Brasil e o Paraguai tornaram-se os maiores produtores de erva-mate e, nesta condição, disputaram mercados externos. Com a guerra entre o Paraguai e a Tríplice Aliança (1864-1870), a economia paraguaia foi desestruturada e o país registrou uma considerável depopulação. Neste cenário, um grupo de pessoas que participaram da guerra e, posteriormente, da demarcação dos limites territoriais entre os dois países (1872-1874) fez parte de um establishment ervateiro que articulou a criação, no antigo sul de Mato Grosso, da Companhia Matte Larangeira. A empresa começou a funcionar no Brasil na década de 1880 e chegou a ter a concessão para explorar uma área de aproximadamente 5 milhões de hectares. A autorização foi suspensa no final da década de 1940 e logo em seguida a empresa formalmente encerrou suas atividades.

Com efeito, a exploração da erva-mate no antigo sul de Mato Grosso foi uma atividade viabilizada para dinamizar a economia e assegurar a definitiva incorporação da região ao território nacional do Brasil. Para isso também foi providenciada a exploração do território, da mão de obra e do conhecimento de comunidades guarani e kaiowá ali estabelecidas, a exemplo do que aconteceu em tempos coloniais no Guairá. Portanto, durante décadas os índios também participaram ativamente da economia regional, embora na condição de subalternidade. Por este motivo nem sempre aparecem como trabalhadores nacionais em fontes oficiais e na historiografia tradicional de viés colonialista.

Em suma, a história da erva-mate é um tema que não se esgota com o presente trabalho, pelo contrário. Necessita ser mais bem estudada e compreendida a partir de uma perspectiva holística que concatene aportes da História e campos afins, notadamente da Arqueologia, Etnologia, Etno-história, Etnobotânica, Sociologia etc. Neste contexto, a memória social dos sujeitos guarani e kaiowá sobre a economia ervateira precisa ser devidamente investigada e valorizada por meio da história oral e da própria etnografia. Dessa forma, sistemas estruturantes de relações sociais de poder e dominação poderão ser mais bem conhecidos no âmbito das ciências humanas e sociais. 


\section{Referências bibliográficas}

ALMEIDA, Mário Monteiro de. Episódios históricos da formação geográfica do Brasil: fixação das raias com Uruguai e Paraguai. Rio de Janeiro: Pongetti, 1951.

ALVES, G. Luiz. Mato Grosso e a história - 1870-1929: ensaio sobre a transição do domínio econômico da casa comercial para a hegemonia do capital financeiro. Boletim Paulista de Geografia, São Paulo, n. 61, p. 5-81, 1984.

ARRUDA, Gilmar. Heródoto. In: Ciclo da erva-mate em Mato Grosso do Sul (18831947). Campo Grande: Instituto Euvaldo Lodi, 1986. p. 195-310. 1997.

Frutos da terra: os trabalhadores da Matte-Larangeira. Londrina: Editora UEL,

BALÉE, William. Contingent diversity on anthropic landscapes. Diversity, Basel (Switzerland), n. 2, v. 2, p. 163-181, 2010.

BALÉE, William et al. Florestas antrópicas no Acre: inventário florestal no geoglifo Três Vertentes, Acrelândia. Amazônica, Belém, n. 6, v. 1, p. 140-169, 2014.

BANDEIRA, Moniz. O expansionismo brasileiro e a formação dos Estados da Bacia do Prata: da colonização à Guerra da Tríplice Aliança. Rio de Janeiro: Editora da Universidade de Brasília, 1998.

BARBOZA, Genésio Pimentel. Relatório do auxiliar Genesio Pimentel Barboza referente ao ano de 1927 e encaminhado ao inspetor Antonio Martins Vianna Estigarríbia. In: MONTEIRO, Maria E. B. (Org.). Levantamento histórico sobre os índios Guarani/Kaiowá. Rio de Janeiro: Museu do Índio, 2003. p. 67-107.

BASTOS, Uacury R. de A. Expansão territorial do Brasil colonial no vale do Paraguai, 1767-1801. 1979. 345 f. Tese (Doutorado em História) - Universidade de São Paulo, São Paulo, [1979].

BONPLAND, Amado. Notas de Amado Bonpland sobre la ventaja de cultivar la planta que produce el mate, de formar montes de ella y de mejorar la fabricación de la yerba mate. Archivo Nacional de Asunción, Sección História, v. 282, n. 18, 1849. In: WHIGHAM, T. La yerba mate del Paraguay (1780-1870). Asunción: Centro Paraguayo de Estudios Sociológicos, 1991. Disponível em: http://www.portalguarani.com/833 thomas_1_whigham/9202_la_yerba_mate_del_parag uay 1780_1870 obra_de thomas_whigham.html. Acesso em 28/01/2015. Acesso em: 28 dez. 2015. 
BRAND, Antonio J. O confinamento e seu impacto sobre os Pãi/Kaiowá. 1993. $158 \mathrm{f}$. Dissertação (Mestrado em História) - Pontifícia Universidade Católica do Rio Grande do Sul, Porto Alegre, [1993].

O impacto da perda da terra sobre na tradição Kaiowá/Guarani: os difíceis caminhos da palavra. 1997. 390 f. Tese (Doutorado em História) - Pontifícia Universidade Católica do Rio Grande do Sul, Porto Alegre, [1997].

BRAND, Antonio J.; FERREIRA, Eva M. L.; ALMEIDA, Fernando A. A. de. Os Kaiowá e Guarani em tempos da Cia Matte Larangeira: negociações e conflitos. In: Anais do XXIII Simpósio Nacional de História - história, guerra e paz. Londrina, ANPUH, CD-ROM. Disponível em: http://anpuh.org/anais/wpcontent/uploads/mp/pdf/ANPUH.S23.0129.pdf. Acesso em: 29 jan. 2015.

BRAUDEL, Fernand. História e Ciências Sociais. Lisboa: Presença, 1990.

BRASIL. Lei $\mathbf{n}^{\circ}$. 601 de 18 de Setembro de 1850. Disponível em: http://www.planalto.gov.br/ccivil_03/Leis/L0601-1850.htm. Acesso em: 02 mar. 2015.

CARDOZO, Efraím. Breve história del Paraguay. Asunción: Litocolor, 1991.

CARDOZO, Ramón I. La antiqua Província de Guairá y la Villa Rica del Espíritu Santo. Buenos Aires: Librería y Casa Editora Jesús Ménéndez, 1968.

CAVALCANTE, Tiago L. V. Colonialismo, território e territorialidade: a luta pela terra dos Guarani e Kaiowa em Mato Grosso do Sul. 2013. 470 f. Tese (Doutorado em Historia) - Universidade Estadual Paulista Júlio de Mesquita Filho, Assis, [2013].

CHAVES, Juliio C. Descubrimiento y conquista del Río de la Plata y el Paraguay. Buenos Aires: Nizza, 1968.

CORRÊA, Valmir B. Coronéis e bandidos em Mato Grosso - 1889-1943. Campo Grande: Editora UFMS, 1995.

Fronteira Oeste. Campo Grande: Editora UFMS, 1999.

CORRÊA FILHO, Virgílio. À sombra dos hervaes mattogrossenses. São Paulo: Ed. São Paulo, 1925.

Ervais e ervateiros. Rio de Janeiro: Ministério da Agricultura, 1957.

História de Mato Grosso. Rio de Janeiro: INL-MEC, 1969.

CORTESÃO, Jaime (Org). Manuscritos da Coleção de Angelis: jesuítas e bandeirantes no Guairá (1594-1640). Rio de Janeiro: Biblioteca Nacional, Divisão de Obras Raras e Publicações, 1951. v. 1-2. 
DONATO, Hernâni. Selva Trágica. São Paulo: Edibolso, 1957.

EREMITES DE OLIVEIRA, Jorge. Cultura material e identidade étnica na arqueologia brasileira: um estudo por ocasião da discussão sobre a tradicionalidade da ocupação Kaiowá da Terra Indígena Sucuri’y. Cultura e sociedade, Goiânia, n. 10, v. 1, p. 95-113, 2007.

A humanização das paisagens pantaneiras pelos povos indígenas: um estudo sobre o uso e manejo da palmeira acuri pelos Guató. In: MORETTI, E. C.; BANDUCCI JUNIOR, Á. (Org.). Pantanal: territorialidades, culturas e diversidade. Campo Grande: Editora UFMS, 2012a. p. 89-116.

A história indígena no Brasil e em Mato Groso do Sul. Espaço Ameríndio, Porto Alegre, v. 6, n. 2, p. 178-218, 2012 b.

EREMITES DE OLIVEIRA, Jorge; VIANA, Sibeli A. O Centro-Oeste antes de Cabral. Revista USP, São Paulo, v. 44, n. 1, p. 142-189, 2000.

EREMITES DE OLIVEIRA, Jorge; PEREIRA, Levi M. Nande Ru Marangatu: laudo antropológico e histórico de uma terra kaiowa na fronteira do Brasil como Paraguai, município de Antônio João, Mato Grosso do Sul. Dourados: Editora UFGD, 2009.

Terra Indígena Buriti: perícia antropológica, arqueológica e histórica sobre uma terra terena na Serra de Maracaju, Mato Grosso do Sul. Dourados: Editora UFGD, 2012.

ESSELIN, Paulo Marcos. A pecuária bovina no processo de ocupação e desenvolvimento econômico do Pantanal Sul-Mato-Grossense (1830-1910). Dourados: Editora UFGD, 2011.

ESSELIN, Paulo Marcos; OLIVEIRA, Tito C. M.; OLIVEIRA, Marco Aurélio M. Fronteiras esquecidas: a construção de hegemonias nas fronteiras entre os rios Paraguai e Paraná. Dourados: Editora UFGD, 2012.

FEIJÓ, Cristiane Tavares. Entre humanos, deuses e plantas: uma etnografia sobre as perspectivas Mbyá Guarani na manutenção das kokue contemporâneas. 2015. 135 f. Dissertação (Mestrado em Antropologia, Área de Concentração em Antropologia Social e Cultural) - Universidade Federal de Pelotas, Pelotas, [2015].

FERREIRA, Eva M. L. A participação dos índios Kaiowá e Guarani como trabalhadores nos ervais da Companhia Matte Larangeira (1902-1952). 2007. $383 \mathrm{f}$. Dissertação (Mestrado em História) - Universidade Federal da Grande Dourados, Dourados, [2007].

FERREIRA, Joaquim J. R. Relatório que o Exm. Sr. Vice Presidente Dr Jose Joaquim Ramos Ferreira devia apresentar a Assembléa Legislativa Provincial de Mato Grosso na $2^{a}$ Sessão da $26^{a}$ Legislatura no dia... de Setembro de 1887. Cuyaba, APMT. Manuscrito. 
GADELHA, Regina. As missões jesuítas do Itatim: estruturas sócio-econômicas do Paraguai colonial - séculos XVI e XVII. São Paulo: Paz e Terra, 1980.

GARAY, Blas. Compendio Elemental de Historia del Paraguay. Madrid-Asunción: Librería y Casa Editora A. de Uribe y Cia, 1896.

GAY, João P. História da república jesuítica do Paraguai: desde o descobrimento do rio da Prata até aos nossos dias, ano de 1861. Rio de Janeiro: Imprensa nacional, 1942.

GERHARDT, Marcos. História ambiental da erva-mate. 2013. 290 f. Tese (Doutorado em História) - Universidade Federal de Santa Catarina, Florianópolis, [2013].

GALLETI, Lylia da S. G. Sertão, fronteira, Brasil: imagens de Mato Grosso no mapa da civilização. Cuiabá: EdUFMT/Entrelinhas, 2012.

GONZÁLEZ LABALE, Alejandro R. Linhas e encrucilhadas, espaço social em um ponto da fronteira Brasil/Argentina. 1996. Dissertação (Mestrado em Antropologia Social) - Universidade Federal de Santa Catarina, Florianópolis, [1996].

GUILLEN, Isabel C. M. A luta pela terra nos sertões de Mato Grosso. Estudos Sociedade e Agricultura, Rio de Janeiro, n. 12, p. 148-168, 1999.

GUSMÁN, Ruy D. de. Anales del descobrimiento, población y conquista del Río de la Plata. Asunción: Comuneros, 1980.

JESUS, Laércio C. de. Erva-mate: o outro lado - a presença dos produtores independentes no antigo sul de Mato Grosso (1870-1970). 2004. 172 f. Dissertação (Mestrado em História) - Universidade Federal de Mato Grosso do Sul, Dourados, 2004.

LANDA, Beatriz dos S. Os Ñandeva/Guarani e o uso do espaço na Terra Indígena Porto Lindo/Jacarey, município de Japorã/MS. 2005. Tese (Doutorado em História/Arqueologia) - Pontifícia Universidade Católica do Rio Grande do Sul, Porto Alegre, [2005].

LANGER, Protásio P. Os Guarani-Missioneiros e o colonialismo luso no Brasil Meridional: projetos civilizatórios e faces da identidade étnica (1750-1798). Porto Alegre: Martins Livreiro, 2005

MATTOS, Joaquim F. de. A Guerra do Paraguai: história de Francisco Solano Lopes, o exterminador da nação paraguaia. Brasília: Centro Gráfico do Senado Federal, 1990.

MARX, Karl; ENGELS, Friedrich. A Ideologia Alemã (I - Feuerbach). São Paulo: Hucitec, 1986.

MEGGERS, Betty. The mystery of the Marajoara: an ecological solution. Amazoniana, Manaus, v. 16, v. 3-4, p. 421-440, 2001. 
MELIÀ, Bartomeu. El encobrimento de América. Acción, Asunción, n. 102, p. 37-41, 1990.

MONTEIRO, John M. Negros da terra: índios e bandeirantes nas origens de São Paulo. São Paulo: Companhia das Letras, 1994.

MONTOYA, Antonio R. de. Tesoro de la lengua Guaraní. Madrid: Iuan Sanches, 1639.

Conquista Espiritual feita pelos religiosos da Companhia de Jesus nas Províncias do Paraguai, Paraná, Uruguai e Tape. Porto Alegre: Martins Livreiro, 1985.

MORAES, Ceres. Paraguai: a consolidação da ditadura de Stroessner (1954-1963). Porto Alegre: Edipucrs, 2000.

NICKSON, Robert A. Colonizacion brasileña en la region fronteriza oriental del Paraguay. Asunción: Centro - Taller de Traducciones Científicas, 1981.

NOELLI, Francisco S. Aportes históricos e etnológicos para o reconhecimento da classificação Guarani de comunidades vegetais no século XVII. Fronteiras, Campo Grande, v. 2, n. 4, p. 275-296, 1998.

A ocupação humana na Região Sul do Brasil: Arqueologia, debates e perspectivas - 1872-2000. Revista USP, São Paulo, v. 44, n. 2, p. 218-269, 2000.

La distribución geográfica de las evidencias arqueológicas Guaraní (Brasil, Argentina, Uruguay y Paraguay). Tellus, Campo Grande, v. 7, n. 2, p. 15-36, 2004.

PARELLADA, Cláudia I. A herança de um tesouro: Arqueologia da cidade colonial espanhola de Villa Rica del Espiritu Santo (1589-1632), Fênix, Paraná. Curitiba: SAMP, 2014.

NOVAES, Sandra N. da S. Ruínas de Xerez: marco histórico do colapso do projeto colonial castelhano em Mato Grosso (1593-1632). 2004. 147 f. Dissertação (Mestrado em História) - Universidade Federal de Mato Grosso do Sul, Dourados, [2004].

PAYRÓ, Roberto P. Historia del Río de la Plata. Buenos Aires: s/ed., Tomo I, 2007.

PEDROSA, Jonathas J. Relatório com que o Exmo. Snr. Dr João José Pedrosa Presidente da Provincia de Mato Grosso abrio a $1^{\mathrm{a}}$ Sessão da $22^{\mathrm{a}}$ Legislatura da respectiva Assembléia no dia $1^{\circ}$ de novembro de 1878. Cuyaba: APMT. Manuscrito.

POLITIS, Gustavo. G. Nukak: Ethnoarchaeology of an Amazonian People. London: Left Coast Press, 2007.

POSEY, Darrell A. Manejo da floresta secundária, capoeiras, campos e cerrados (Kayapó). In: RIBEIRO, Berta G. (Org.). Suma Etnológica Brasileira. Petrópolis: Vozes/Finep, 1987. v. 1. p.173-185. 
QUEIROZ, Paulo R. C. As curvas do trem e os meandros do poder: o nascimento da estrada de ferro noroeste do Brasil (1904-1908). Campo Grande: Editora da UFMS, 1997.

Joaquim Murtinho, banqueiro: notas sobre a experiência do Banco Rio e Mato Grosso (1891-1902). Estudos Históricos, Rio de Janeiro, v. 23, n. 45, p. 125-146, 2010 a.

A grande empresa conhecida como Mate Laranjeira e a economia ervateira na bacia platina (1882-1949): notas preliminares. In: DANTAS, C.; ABREU, M. (Org.). Primeiro Encontro de Pós-doutores do PPGH/UFF. Niterói: PPGH/UFF, 2010b. p. 119.

RAMOS, Jorge A. Las masas y las lanzas. Buenos Aires: Plus Ultra, 1974.

SANTOS, A. L. Officio do Diretor Geral dos Índios em Cuyaba Antonio Luis Santos ao Presidente da Província ILLmo e Exmo Senr General Jose de Miranda da Silva Reis. Manuscrito. Lata 1885E. Cuyaba, APMT, 1885. Manuscrito.

SILVA, Meire A. da. O movimento dos Guarani e Kaiowá de reocupação e recuperação de seus territórios em Mato Grosso do Sul e a participação do Conselho Indigenista Missionário (CIMI). 2005. 103 f. Dissertação (Mestrado em História) Universidade Federal de Mato Grosso do Sul, Dourados, 2005.

SMITH, Herbert H. Do Rio de Janeiro a Cuyabá: notas de um naturalista. São Paulo: Companhia Melhoramentos, 1921.

SUSNIK, Branislava. El indio colonial del Paraguay: el Guaraní colonial. Asunción: Museo Etnográfico Andrés Barbero, 1965.

VILELA DA SILVA, Jovam. Um truste encravado no Sul de Mato Grosso (1882-1950). Coletâneas de Nosso Tempo, Cuiabá, v. 1, p. 26-44, 1997.

WHIGHAM, Thomas. La yerba mate del Paraguay (1780-1870). Asunción: Centro de Estudios Sociológicos, 1991. Disponível em: http://www.portalguarani.com/833 thomas_1_whigham/9202_la_yerba_mate_del_parag uay_1780_1870_obra_de_thomas_whigham.html. Acesso em: 29 jan. 2015.

WHIGHAM, Thomas; POTTHAST, Barbara. The Paraguayan Roseta Stone: new insights into the demographics of the Paraguayan War, 1864-1870. Latin American Research Review, v. 34, n. 1, 1999.

WILDE, Guillermo. Toward a Political Anthropology of Mission Sound: Toward a Political Anthropology of Mission Sound: Paraguay in the 17th and 18th Centuries. Music \& Politics, Michigan, v. 1, n. 2, p. 1-29, 2007. 
Recebido em: 08/04/2015 * Aprovado em: 19/08/2015 * Publicado em: 31/12/2015 318, jul./dez. 2015. 